\title{
Thermal Performance of Compression Ignition Engine Using High Content Biodiesels: A Comparative Study with Diesel Fuel
}

\author{
Asif Afzal ${ }^{1, *(\mathbb{D})}$, Manzoore Elahi M. Soudagar ${ }^{2}\left(\mathbb{D}\right.$, Ali Belhocine ${ }^{3}$, Mohammed Kareemullah ${ }^{1}$, Nazia Hossain ${ }^{4, *}$, \\ Saad Alshahrani ${ }^{5}$, Ahamed Saleel C. ${ }^{5}$,, Ram Subbiah ${ }^{6}\left(\mathbb{D}\right.$, Fazil Qureshi ${ }^{7}$ and M. A. Mujtaba ${ }^{8}(\mathbb{D}$ \\ 1 Department of Mechanical Engineering, P. A. College of Engineering, Affiliated to Visvesvaraya \\ Technological University, Belagavi, Mangaluru 574153, India; kareemulla.mech@pace.edu.in \\ 2 Department of Mechanical Engineering, Glocal University, Delhi-Yamunotri Marg, \\ Mirzapur Pole 247121, India; me.soudagar@gmail.com \\ 3 Faculty of Mechanical Engineering, University of Sciences and the Technology of Oran, 31000 Oran, Algeria; \\ al.belhocine@yahoo.fr \\ 4 School of Engineering, RMIT University, Melbourne, VIC 3000, Australia \\ 5 Department of Mechanical Engineering, College of Engineering, King Khalid University, P.O. Box 394, \\ Abha 61421, Saudi Arabia; saadayed@kku.edu.sa (S.A.); ahamedsaleel@gmail.com (A.S.C.) \\ 6 Gokaraju Rangaraju Institute of Engineering \& Technology, Hyderabad 500090, India; ram4msrm@gmail.com \\ 7 Department of Petroleum Engineering, Glocal University, Delhi-Yamunotri Marg, SH—57, Mirzapur Pole, \\ Saharanpur District, Mirzapur Pole 247121, India; fazilqureshi@theglocaluniversity.in \\ check for \\ updates \\ Citation: Afzal, A.; \\ Soudagar, M.E.M.; Belhocine, A.; \\ 8 Department of Mechanical Engineering, Faculty of Engineering, University of Malaya, \\ Kuala Lumpur 50603, Malaysia; m.mujtaba@uet.edu.pk \\ * Correspondence: asif.afzal86@gmail.com (A.A.); bristy808.nh@gmail.com (N.H.)
} Kareemullah, M.; Hossain, N.; Alshahrani, S.; Saleel C., A.; Subbiah, R.; Qureshi, F.; Mujtaba, M.A. Thermal Performance of Compression Ignition Engine Using High Content Biodiesels: A Comparative Study with Diesel Fuel. Sustainability 2021, 13, 7688. https:// doi.org/10.3390/su13147688

Academic Editor: Enrique

Rosales-Asensio

Received: 12 April 2021

Accepted: 28 June 2021

Published: 9 July 2021

Publisher's Note: MDPI stays neutral with regard to jurisdictional claims in published maps and institutional affiliations.

Copyright: (c) 2021 by the authors. Licensee MDPI, Basel, Switzerland. This article is an open access article distributed under the terms and conditions of the Creative Commons Attribution (CC BY) license (https:// creativecommons.org/licenses/by/ $4.0 /)$.

Abstract: In this study, engine performance on thermal factors for different biodiesels has been studied and compared with diesel fuel. Biodiesels were produced from Pongamia pinnata (PP), Calophyllum inophyllum (CI), waste cooking oil (WCO), and acid oil. Depending on their free fatty acid content, they were subjected to the transesterification process to produce biodiesel. The main characterizations of density, calorific range, cloud, pour, flash and fire point followed by the viscosity of obtained biodiesels were conducted and compared with mineral diesel. The characterization results presented benefits near to standard diesel fuel. Then the proposed diesel engine was analyzed using four blends of higher concentrations of B50, B65, B80, and B100 to better substitute fuel for mineral diesel. For each blend, different biodiesels were compared, and the relative best performance of the biodiesel is concluded. This diesel engine was tested in terms of BSFC (brake-specific fuel consumption), BTE (brake thermal efficiency), and EGT (exhaust gas temperature) calculated with the obtained results. The B50 blend of acid oil provided the highest BTE compared to other biodiesels at all loads while B50 blend of WCO provided the lowest BSFC compared to other biodiesels, and B50 blends of all biodiesels provided a minimum \% of the increase in EGT compared to diesel.

Keywords: diesel engine; Pongamia pinnata; Calophyllum inophyllum; waste cooking oil; acid oil; performance

\section{Introduction}

Energy is a vital input for economic growth, human welfare, enhancing the quality of life, and social development. Recently, a steep increment in industrialization, improvement and modernization has led to more demand for petroleum worldwide [1,2]. The key source of energy in transportation, agriculture, and industry is diesel [3]. Diesel is used as an energy source throughout the world due to its flexibility, combustion efficiency, reliable nature, ease of handling, and consistency [4,5].

Developing countries are in need of oil to meet their energy needs; subsequently, therefore, they import oil. In addition, to high energy demand, which has led to an energy 
crisis, fossil fuel use is causing environmental issues [6]. Thus, depleting resources of fossil fuel and environmental pollution are the two major issues faced by society $[7,8]$. International perception of the energy crunch and the repercussions associated with fossil fuels on the environment has led to probe the viewpoint of utilizing alternative energy resources like biodiesel $[9,10]$. Biodiesel is a mono-alkyl ester of long-chain fatty acids (FAME) obtained from renewable lipids such as animal fats, vegetable oils, and alcohol. Biodiesel is biodegradable, non-toxic, renewable, and readily available. Furthermore, a higher flash point, cetane ignition rating, and inherent lubricity contribute to a further reduction in emissions in contrast to diesel [11,12]. Many researchers have analyzed various biodiesels and their blends, among them Calophyllum inophyllum (CI) or Polanga, waste cooking oil (WCO) and Pongamia pinnate (PP) are among the extensively explored resources from, which biodiesel can be produced; transesterification process for producing biodiesel in particular, involves using monohydric alcohols like ethanol and methanol with $\mathrm{NaOH}$ catalyst [13]. For producing biodiesel, various stages of the transesterification process are utilized based on its free fatty acid level [14].

Sahoo et al. [15] used polanga biodiesel-diesel blends at different engine speeds and loads, specifically at high speed; at these conditions, an engine study revealed that Polanga biodiesel could be used in a diesel engine without any modifications, which is a good sign of alternative fuel. Flashpoint is high for polanga biodiesel, which helps store biodiesel safely. Polanga biodiesel blends showed better performance and emission characteristics than diesel engine. Non-edible Karanja (PP), CI, and Jatropha (Jatropha curcas) biodiesel produced from their respective oils when it was blended with diesel showed a sulfur content of $10 \mathrm{mg} / \mathrm{kg}$ was shown by Sahoo et al. [16] Engine speed was changed for a three-cylinder tractor engine. viscosity, density, calorific value, pour point, and flashpoint of oils were enhanced due to transesterification of oils. BSFC showed a decrease with an increase in speed and an increase in blends. The use of blends reduced the smoke compared to diesel. Hydrocarbons, particulate matter, and exhaust smoke decreased with increase in biodiesel content in the blend.

Ong et al. [17] use Ceiba pentandra, CI, and Jatropha curcas oil for the production of biodiesel by two-step transesterification and biodiesel was used in the diesel engine. B10 showed better performance and emission characteristics, which reduced $\mathrm{CO}, \mathrm{HC}$, and smoke; BSFC showed an increase, and BTE showed a decrease. Reduction BSFC is the result of complete combustion. Fattah et al. [18] investigated the effect of antioxidants in diesel engines on performance and emissions. One step esterification was used to produce CI. B20 blend of CI in diesel engine showed reduced brake power and increased in BSFC, but the use of antioxidants increased the brake power and reduced BSFC. The use of antioxidants reduced NOx compared to the B20 blend of CI.

The aim of Sajjad et al. [19] was to conduct and advance the effectiveness of the diesel engine by analyzing characteristics of the pollutant emissions by utilizing a blend of CI biodiesel, diesel, and GTL (gas to liquid) fuel (DCIG20) and then relating it also with traditional blends of GTL-diesel (G20) and biodiesel-diesel (CI20). The BTE was higher but obtained low BSEC and BSFC in G20 compared to the other two blends, whereas emissions were reduced in all the blends [19]. Savariraj et al. [13] blended different proportions of high-viscous non-edible tamanu oil (vegetable oil) blended with ethanol solution. They utilized it in a standard diesel engine to investigate its efficiency and pollutant emissions. At full load, the test fuel mixtures exhibited a reduction in BTE by $16 \%$, an increase in BSFC, i.e., nearly $33.5 \%, 5.8 \%$ reduction in exhaust gas temperature, carbon monoxide was reduced by $1.1 \%$, nitrogen oxide reduced by $45 \%$, hydrocarbon increased by $68 \%$, and $28 \%$ more smoke emission was recorded when it related with the diesel fuel at entire load condition.

Manufacturing of biodiesel from CI and palm oil and performance of the engine evaluation was carried by Ashrafur et al. [20] at lower loads. Engine speeds of $1000 \mathrm{rpm}$, $1200 \mathrm{rpm}, 1500 \mathrm{rpm}$ at loads of $10 \%, 12 \%$, and $15 \%$ were the conditions for the CI blends of B5, B10, and B20. BSFC was lower in diesel than CI and palm oil. BSFC was lower for CI 
when compared to palm oil biodiesel due to the lower calorific value of palm oil biodiesel. At $1500 \mathrm{rpm}$, the rise in BSFC was lower due to higher temperature and intrinsic oxygen present. BTE is better for CI biodiesel compared to palm biodiesel. Palm biodiesel emitted higher emissions than $\mathrm{CI}$ biodiesel due to higher viscosity causing incomplete combustion. However, at a higher speed, NOx emission was lower due to a shorter ignition delay period. Ong et al. [21] classified the performance, production, and emission of Jatropha curcas, CI, and palm oil biodiesel. Combustion characteristics of biodiesel were almost like mineral petroleum-diesel fuel, and the biodiesel blend minimized smoke opacity, HC, $\mathrm{CO}, \mathrm{CO}_{2}$ emissions, and particulate matters, but $\mathrm{NOx}$ emissions were increased slightly. The ability of $\mathrm{CI}$ was served as promising feedstock for the production of biodiesel and its chemical and physical properties; fatty acid composition ester was scrutinized and studied by Atabani et al. [22]. Performance of the engine and emissions, the effect of adding antioxidants, crude oil-diesel blending, biodiesel-biodiesel blending, and biodiesel-diesel blending of CI methyl were also experimented with.

The transesterified CI, and the physical properties of this biodiesel were tested by Hegde et al. [23] SC5D was used as an additive in the blends. B10, B20, B30, and B40 were the blends prepared and used for engine studies. The effect of using additives was reduction in fuel consumption and an increase in BTE. On the other hand, higher biodiesel content caused an increase in NOx and exhaust as temperature. Hwang et al. [24] used WCO as biodiesel and investigated the effect of different load and injection pressure. There were long delays triggered as biodiesel-fuel obtained peak viscosity related to petroleumdiesel fuel. Viscosity caused the increase in friction in the nozzle. Due to the high viscosity of biodiesel blends, the peak cylinder pressure of biodiesel is lower than that of diesel, which is also due to low calorific value and lower mixing of air and fuel. Biodiesel was produced from acid oil obtained from vegetable oil refineries, one of the by-products of these oil refineries by Kulkarni et al. [25]. The acid oil has a FFA (free fatty acid) value of $87 \%$. Acid oil biodiesel produced by the esterification process showed 70 to $80 \%$ biodiesel yield. Properties of biodiesel varied with the variety of sources.

Suresh Kumar et al. [26] used PP biodiesel and tested the properties of biodiesel and conducted engine performance studies for different blends. An increase in load showed a decrease in BSFC. Up to B60 there was no CO content in emissions because of incomplete combustion. $\mathrm{CO}_{2}$ was reduced in $\mathrm{B} 40$ blend due to lesser carbon content. An increase in biodiesel content in the blend increased the viscosity, which led to higher $\mathrm{HC}$ and $\mathrm{CO}$ emissions. EGT decreased with an increase in biodiesel content; increased EGT is a sign of complete combustion. The blend with better characteristics was B40 blend. Bojan et al. [27] used Jatropha curcas for the production of biodiesel. Higher FFA content in Jatropha reduced the yield. Christensen et al. evaluated the stability and aging characteristics of biodiesel. [28]. Use of antioxidants reduced the degradation of biodiesel. Recently, Rajesh et al. [29] analyzed the injection parameter's effect on a diesel engine for acid oil with ethanol added as an additive. However, no comparison was made with any other biodiesel, as reported by the authors. Similar studies are also reported in [30-41].

From the above literature review, we can infer that major work utilizing blends of higher concentrations of PP, CI, WCO, and acid oil as biodiesel has not yet been conducted. Nonetheless, research has been reported in the field with a potent effect and combination of biodiesel from acid oil and biodiesel from PP, CI, and WCO fueled in the diesel engine. The availability, extraction, and production of biodiesel from CI, PP are mentioned [15]. WCO can be obtained from restaurants, roadside vendors. Next, this work's prime aim and scope are to generate biodiesel blends from PP oil, CI oil, acid oil, and WCO of higher concentrations that are available and not feasible for human consumption. Evaluation and comparison of the physicochemical assets of biodiesel fuel and its blends are also performed. In this research work, the biodiesel was tested and compared with the diesel engine by blending different percentages with mineral diesel fuel to analyze its performance and pollutant emissions. 


\section{Materials and Methods}

Biodiesel from PP oil and CI oil can be produced by methods mentioned in the previous experimental literature $[15,22,29]$. WC oil is readily available from restaurants and roadside vendors. As biodiesel extraction from acid oil is not reported, in this section we provide biodiesel production from it.

\subsection{Bio-Refinery Process of Biodiesel from Acid Oil}

Biodiesel from acid oil cannot be produced directly from the bio-refinery process, as the FFA value is very high. However, it could be produced by reducing the FFA value by using $20 \%$ concentration $\mathrm{H}_{2} \mathrm{SO}_{4}$ and methanol in a 1:1 ratio. Therefore, the following procedure was followed to produce biodiesel from acid oil. One liter of oil was first transferred into a three-neck flask, as shown in Figure 1a. The three-neck typed bottle was placed on a magnetic stirrer, and the setup was maintained and controlled to $60{ }^{\circ} \mathrm{C}$ temperature. One liter of methanol was taken in a separate flask and to it was added $20 \mathrm{~mL}$ of concentrated $\mathrm{H}_{2} \mathrm{SO}_{4}$. This methanol and $\mathrm{H}_{2} \mathrm{SO}_{4}$ mixture was added to the three-neck flask and maintained at $60^{\circ} \mathrm{C}$ temperature for three hours stirred at $200 \mathrm{rpm}$ (constant speed). After three hours of continuous heating and stirring, biodiesel was extracted. The obtained biodiesel contained impurities like acid and methanol. The obtained biodiesel was transferred into the washing funnel. It was necessary to rinse and wash it with water. This was done by mixing biodiesel with water of equal proportions. One liter of biodiesel was taken and filled in the washing funnel, and the same quantity of water was filled in the washing funnel and stirred well; it was then permitted to settle down for one day. The water settled below, and the crude biodiesel (acid oil) settled above, as shown in Figure 1b. The water was drained out, and the same procedure was repeated with fresh water two to three times. The crude biodiesel was then taken for distillation.

\subsection{Distillation of Biodiesel}

Purification is the process of warming a liquid to create vapor, which is composed when cooled and detached from the unique liquid. The distillation unit of biodiesel is as shown in Figure 1c. First, the distillation unit is cleaned, and one liter of biodiesel is poured into it. Next, this unit is heated until the vapor temperature is reached. When the vapor condenses at the top of the distillation unit, it is collected in a separate clean container, as presented in Figure 1c.

\subsection{Groundwork of Test Fuel Blends}

Distilled biodiesels of necessary amounts were taken for the mixing process. Diesel is collected from the local retail outlet at Davanagere, India. Two burettes were taken and cleaned with acetone to avoid contamination of fuels. For the first blend, $50 \mathrm{~mL}$ of biodiesel and $50 \mathrm{~mL}$ of diesel were mixed in a 50:50 ratio to prepare blend B50. Similarly, other blends of biodiesel diesel were prepared for B65 and B80 for prepared biodiesels, i.e., acid oil methyl ester, waste cooking oil methyl ester, Pongamia pinnata methyl ester, and Calophyllum inophyllum methyl ester. The blends were stirred for five minutes using a magnetic and electric motor stirrer for homogeneity.

\subsection{Measurement of Properties of Biodiesel}

For this process, a normal flask with $25 \mathrm{~mL}$ capacity was used to quantify the density of the fuel at different temperatures. The amount of the static volume of the test fuel $(25 \mathrm{~mL})$ was analyzed at varied temperatures by an electronic balance up to $0.0001 \mathrm{gm}$, and the density of the test fuel was quantified in $\mathrm{kg} / \mathrm{m}^{3}$. Generally, laboratory equipment was used to measure the following properties. The flashpoint and fire point were measured by ASTM D92 standard procedure using the Pensky Martin flash and fire point apparatus. Similarly, ASTM D5865 procedures were followed to estimate the test fuel (calorific range) of the produced biodiesels by the pour bomb calorimeter. ASTM D92 procedure was followed to measure kinematic viscosity using, say bolt viscometer. 


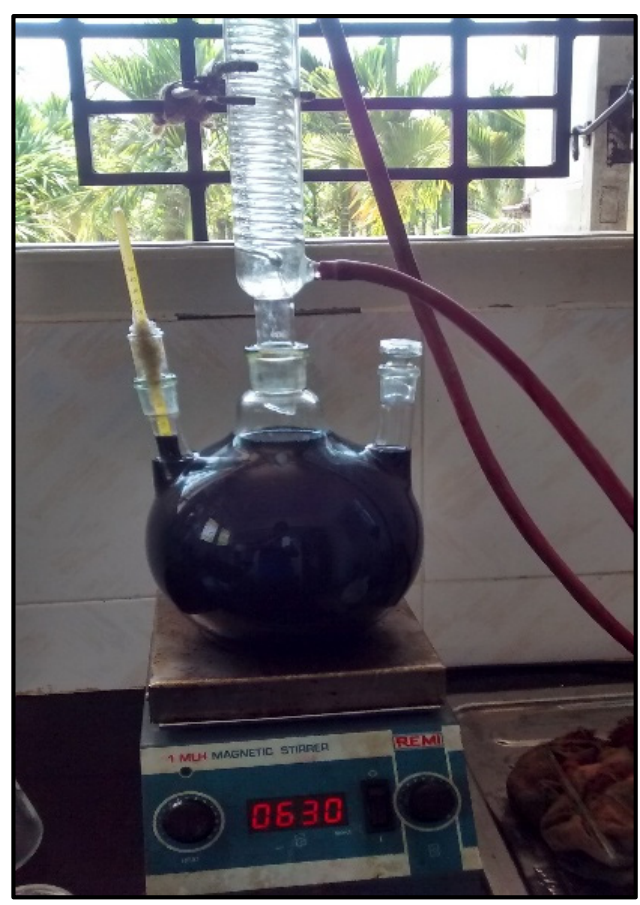

(a)

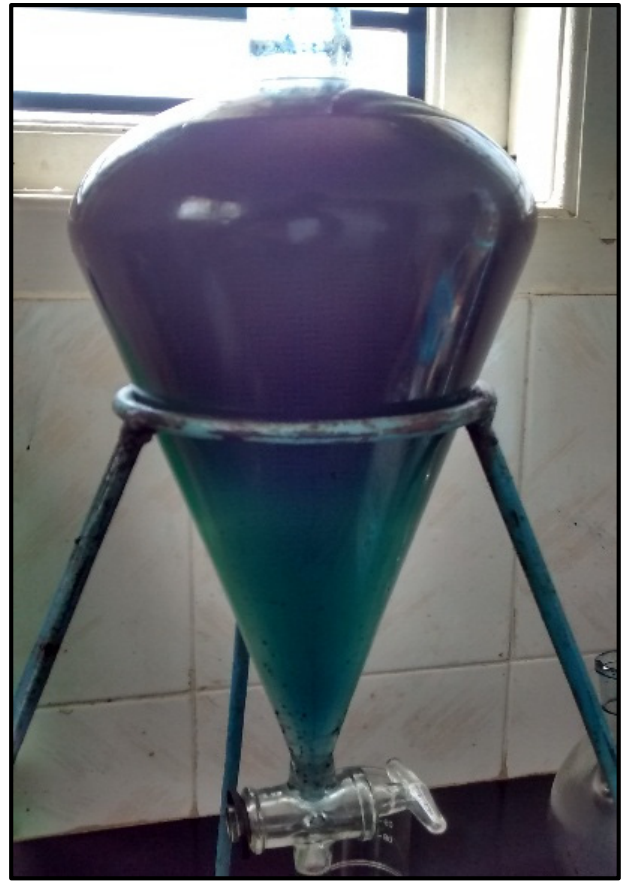

(b)

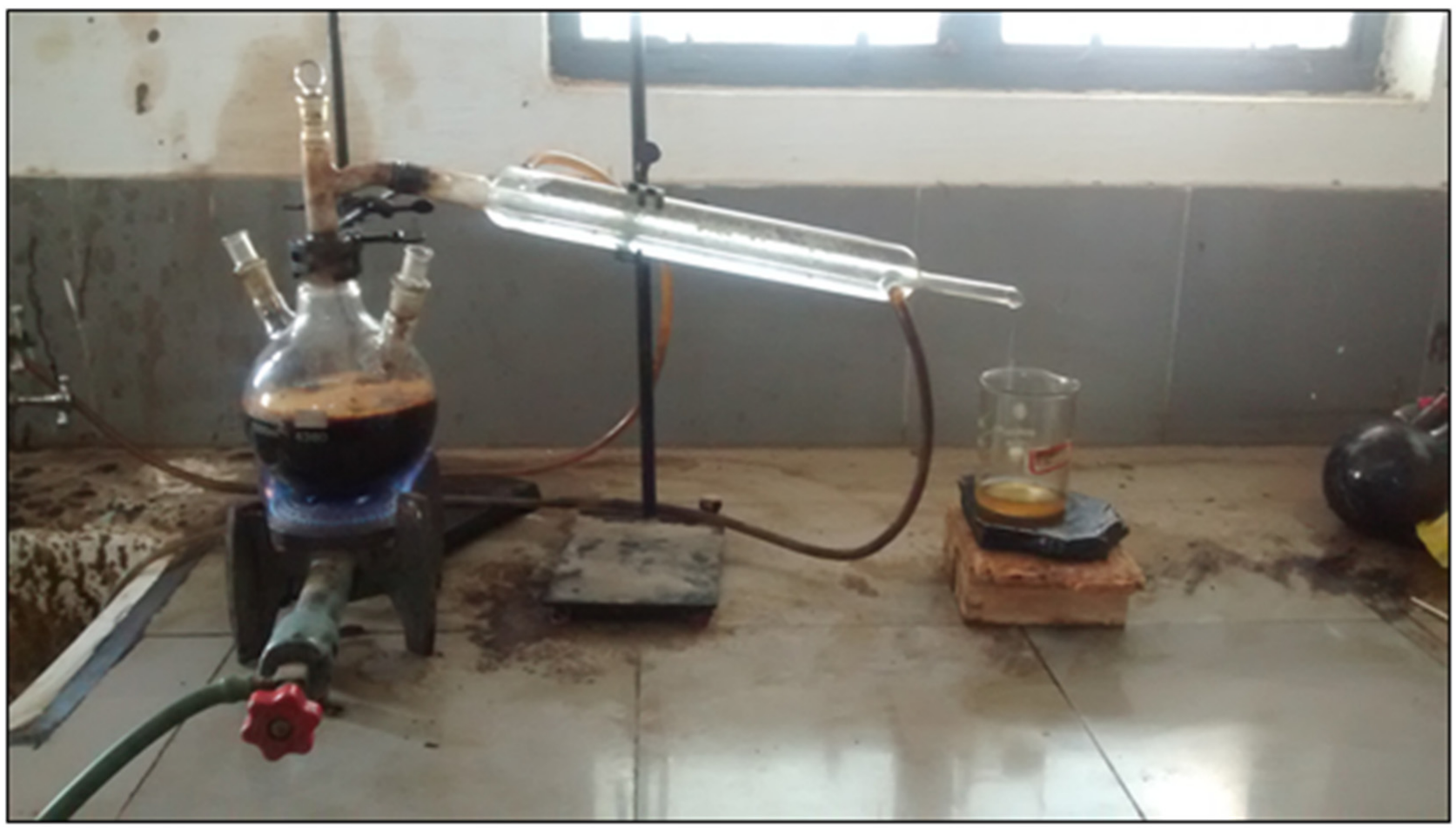

(c)

Figure 1. Flask, settling chamber, and distillation process used for biodiesel extraction from acid oil in this study. (a) Transesterification reaction taking place in 3 necked flasks. (b) Biodiesel of Acid oil settling at the top (purple color). (c) Distillation of biodiesel.

\subsection{Infrared Spectroscopic Analysis}

The infrared spectroscopic analysis was carried out using a Bruker FTIR (field transmission infrared spectrum) spectrophotometer (Alpha T), integrated with the Free Fatty Acid Methyl Ester (FAME) wizard software for data processing. Afterward, obtained 
biodiesel was isolated and scrutinized by $1 \mathrm{H}$ nuclear magnetic resonance (NMR) on a Bruker DPX 200 spectrometer and Bruker DPX 400 apparatus for the recycled process of reactions. To analyze the yield of the transesterification reaction, the $1 \mathrm{H}$ NMR technique was utilized.

\subsection{Engine Specifications}

The specification of the engine used for the performance evaluation of different biodiesel blends is mentioned in Table 1 . The diesel engine setup used to assess the performance of different biodiesel and its blends as shown in Figure 2a,b. The engine is operated at a constant speed of $1500 \mathrm{rpm}$, at an injection timing of $23^{\circ} \mathrm{BTDC}$, water-cooled, 210 bar injection pressure at room temperature. The maximum power of the engine is $5.2 \mathrm{~kW}$. Initially, the engine is operated on diesel fuel and considered as the baseline, and then at later stages, four different biodiesel fuel blends are used in the current investigation. The readings were obtained at different brake power $(0.588,1.1764,1.7647,2.3529,2.9411$, $3.5294 \mathrm{~kW}$ ) for four biodiesel fuel blends.

Table 1. Proposed diesel engine specifications.

\begin{tabular}{cc}
\hline Parameter & Specifications \\
\hline Engine type & Kirloskar TV-1, 4-stroke single-cylinder, water-cooled \\
Bore & $87.5 \mathrm{~mm}$ \\
Stroke & $110 \mathrm{~mm}$ \\
Compression ratio & $17.5: 1$ \\
Speed & $1500 \mathrm{rpm}$ \\
Power & $5.2 \mathrm{~kW}$ \\
Fuel injection & Mechanical injection with injection timing $23^{\circ}$ BTDC, 210 \\
& bar injection pressure. \\
\hline
\end{tabular}

\section{Results}

\subsection{Fuel Properties}

The different properties of oils under investigation, which are necessary to know before preparation of biodiesels from them for utilizing them in engine performance evaluation, are cited in Table 2.

Table 2. Properties of different oils applied for this experimental study.

\begin{tabular}{cccccc}
\hline Properties & $\begin{array}{c}\text { Raw Acid Oil from } \\
\text { Rice Bran }\end{array}$ & $\begin{array}{c}\text { Raw Acid Oil from } \\
\text { Sunflower }\end{array}$ & CI Oil & PP Oil & WCO \\
\hline Density kg/m $/ \mathrm{m}^{3}$ & 875 & 882 & 895 & 890 & 875 \\
Flash point ${ }^{\circ} \mathrm{C}$ & 156 & 192 & 220 & 215 & 198 \\
Fire point ${ }^{\circ} \mathrm{C}$ & 208 & 199 & 228 & 220 & 205 \\
Calorific value $\mathrm{MJ} / \mathrm{kg}$ & 30.1542 & 34.96007 & 37.25436 & 30.400 & 35.00729 \\
Kinematic viscosity (cSt) & 38 & 36 & 48 & 39 & 6 \\
\hline
\end{tabular}

3.2. Fuel Properties of Biodiesels from Acid Oil, Pongamia Pinnata (PP, Honge), Waste Cooking Oil (WCO) and Calophyllum Inophyllum (CI)

Obtained FAME properties of biodiesel from acid oil, PP (also known as Honge), CI, and WCO in comparison with petroleum-diesel be present in Table 3. 


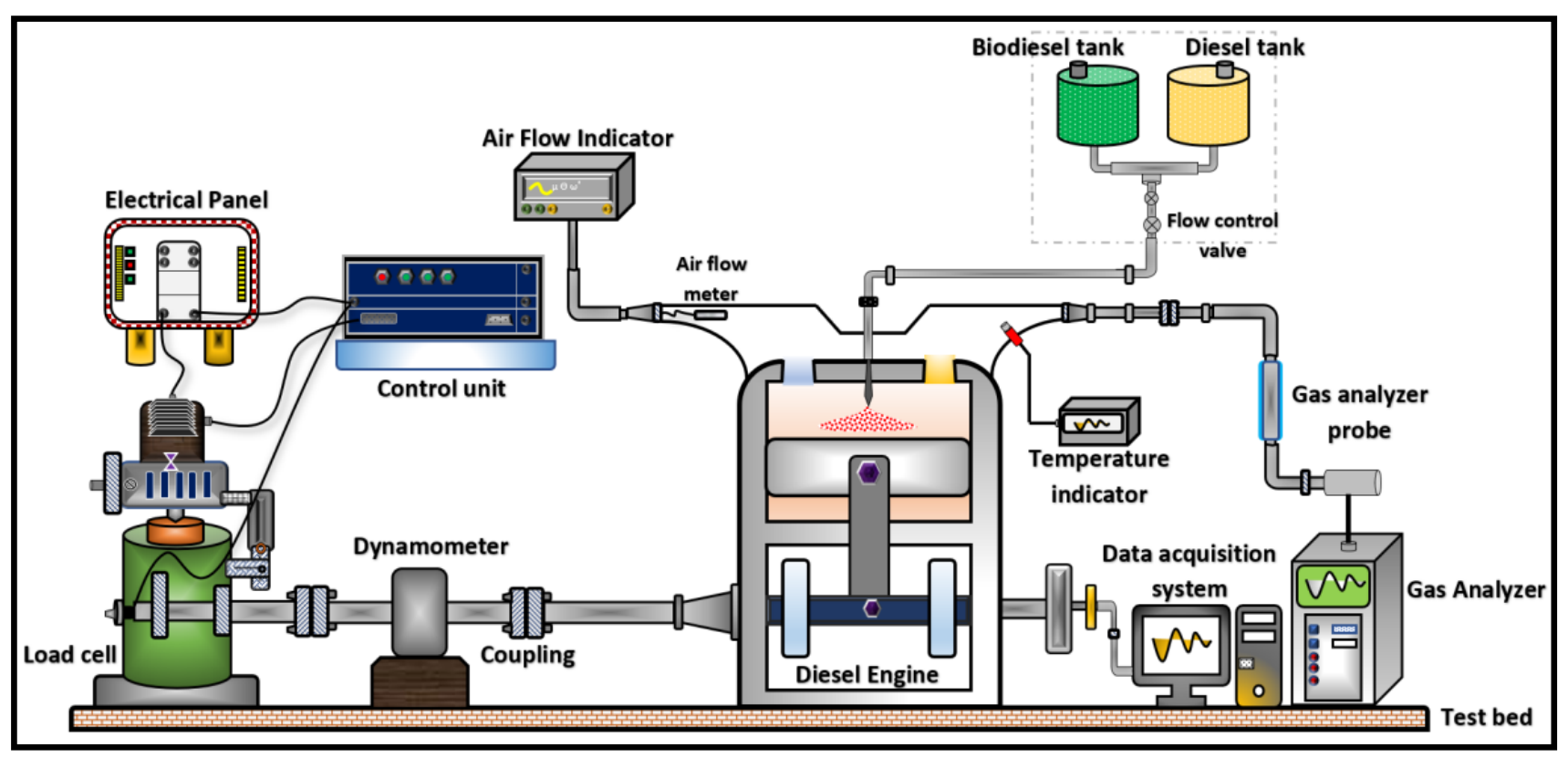

(a)

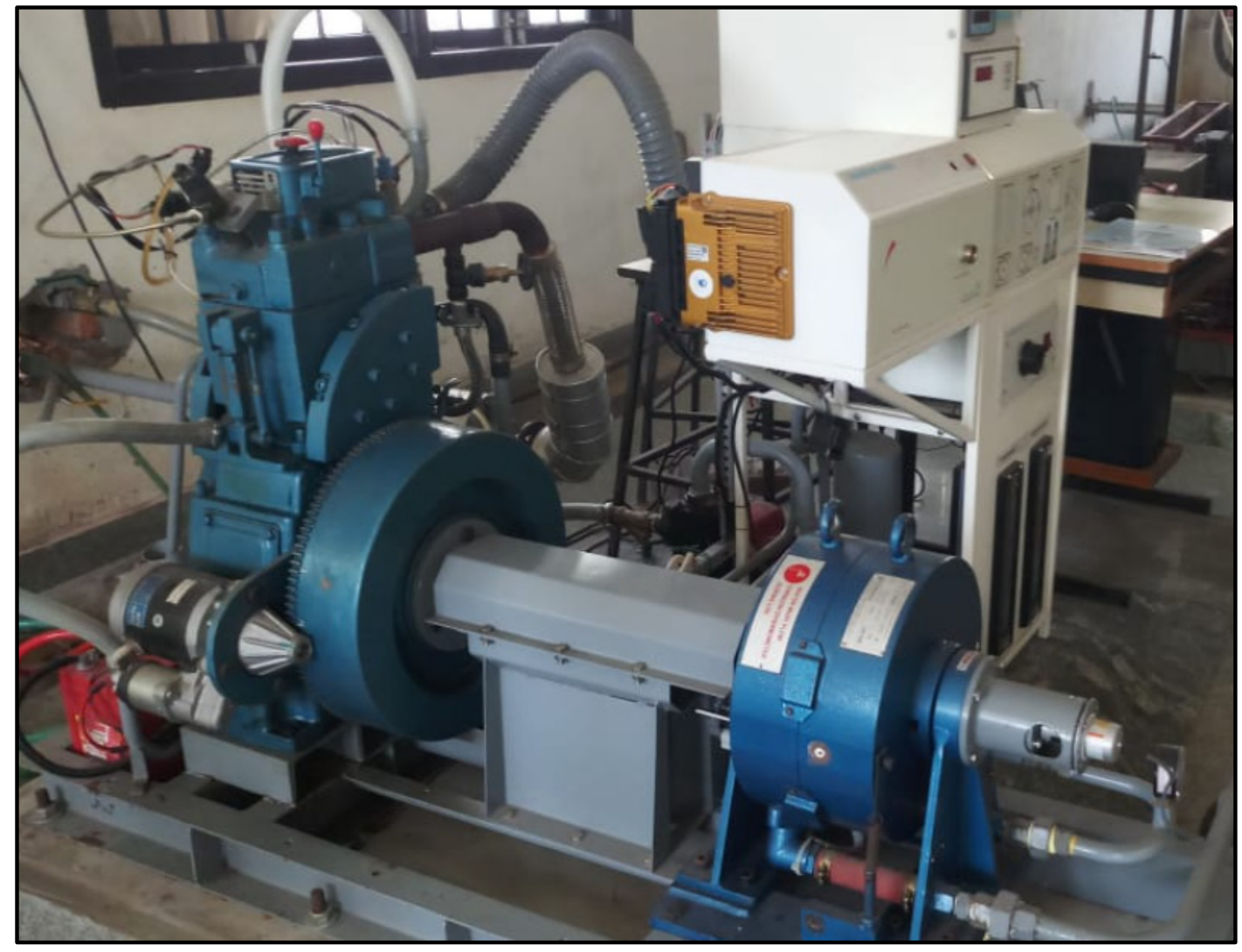

(b)

Figure 2. (a) Schematic diagram of the experimental setup of the diesel engine used for analysis [30], (b) Pictorial representation of diesel engine setup. 
Table 3. Fuel properties of blends of FAME (Free Fatty Acid Methyl Ester) from PP (Honge), CI, acid Oil, and WCO.

\begin{tabular}{|c|c|c|c|c|c|c|}
\hline Biodiesel & Blends & $\begin{array}{l}\text { Density } \\
\mathrm{kg} / \mathrm{m}^{3}\end{array}$ & $\begin{array}{c}\text { Calorific Value } \\
\mathrm{kJ} / \mathrm{kg}\end{array}$ & $\begin{array}{l}\text { Viscosity } \\
\text { cSt }\end{array}$ & Flash Point ${ }^{\circ} \mathrm{C}$ & Fire Point ${ }^{\circ} \mathrm{C}$ \\
\hline \multirow{4}{*}{ PP (Honge) } & B50:D50 & 852 & $39,443.6$ & 5.81 & 58 & 66 \\
\hline & B65:D35 & 860 & $38,526.6$ & 6.82 & 74 & 78 \\
\hline & B80:D20 & 873 & $37,609.8$ & 7.11 & 86 & 90 \\
\hline & B100 & 885 & $36,708.7$ & 8.08 & 98 & 103 \\
\hline \multirow{4}{*}{ Acid oil } & B50:D50 & 848 & $39,341.4$ & 4.40 & 58 & 62 \\
\hline & B65:D35 & 856 & $38,393.8$ & 4.88 & 54 & 62 \\
\hline & B80:D20 & 874 & $37,446.3$ & 5.46 & 64 & 70 \\
\hline & B100 & 887 & $36,501.8$ & 5.91 & 78 & 86 \\
\hline \multirow{4}{*}{ CI } & B50:D50 & 844 & $40,806.3$ & 4.71 & 60 & 68 \\
\hline & B65:D35 & 856 & $40,298.2$ & 5.24 & 72 & 90 \\
\hline & B80:D20 & 868 & $39,790.1$ & 6.27 & 90 & 98 \\
\hline & B100 & 881 & $39,059.6$ & 7.02 & 105 & 115 \\
\hline \multirow{4}{*}{ WCO } & B50:D50 & 836 & $41,818.4$ & 3.79 & 62 & 70 \\
\hline & B65:D35 & 856 & $41,613.9$ & 3.83 & 78 & 84 \\
\hline & B80:D20 & 868 & $41,409.5$ & 4.68 & 92 & 102 \\
\hline & B100 & 879 & $41,298.2$ & 4.98 & 112 & 124 \\
\hline Diesel & D100 & 845 & $42,500.3$ & 3.45 & 53 & 64 \\
\hline
\end{tabular}

\section{Infrared spectrum (IR) of acid oil.}

The infrared spectrum (IR spectrum) of acid oil biodiesel, as obtained in FTIR, is shown in Figure 3. The biodiesel embodied all the absorption bands that are usually detected in the IR spectra of diesel [31,32]. As the nature, size, and reactive number of active compounds are based on the properties of biodiesel fuel, a spectral analysis was carried out. A Fourier transform infrared spectroscopy-attenuated total reflectance (FTIR-ATR) spectrometer (Bruker alpha device built-in diamond ATR) was used for the IR spectroscopic study. The sample of biodiesel comprises primarily a saturated and unsaturated FAME compound mixture. The $3000-3500 \mathrm{~cm}^{-1}$ spectrum does not include any peaks, which show that no kind of aromatic replacement compounds is present in the sample. The inclusion of the methyl ester group at a single end indicated by a broad characteristic band at $1700 \mathrm{~cm}^{-1}$. In the area $3400-3600 \mathrm{~cm}^{-1}$, there are no peaks, which indicates that the sample does not contain moisture or methanol. This spectral analysis shows clearly that the fatty acids are converted into methyl esters almost completely.

\section{Engine Performance Characteristics}

In this section, we describe the results obtained during performance evaluation of biodiesels of blends B50 (50\% biodiesel and 50\% diesel), B65 (65\% biodiesel and 35\% diesel), B80 ( $80 \%$ biodiesel and 20\% diesel), and B100 (100\% biodiesel) obtained from CI, PP (also known as Honge), acid oil (AO) and WC oil. A comparison with diesel performance is done for each blend of different biodiesels. Performance is also evaluated between the mixtures of particular biodiesel. The following engine analysis was performed at an injection angle of $23^{\circ}$ BTDC and part load conditions with pressure 210 bar and speed $1500 \mathrm{rpm}$. PP (Pongamia pinnata) is mentioned as Honge now onwards in the text and graphs. Here, Blends B50 and B65 are considered as lower, whereas B50 is the lowest blend. On the other side, B80 and B100 are regarded as higher blends, with B100 as the top blend. Loads from $0.588 \mathrm{~kW}$ to 1.764 are mentioned as lower load conditions and $0.588 \mathrm{~kW}$ as the lowest. Similarly, $2.3529 \mathrm{~kW}$ to $3.5294 \mathrm{~kW}$ are referred to as higher loads with $3.5294 \mathrm{~kW}$ as the highest load. Maximum power up to which the engine can be operated is $5.2 \mathrm{~kW}$ with torque of $33.1 \mathrm{~N}-\mathrm{m}$. In this study, we have conducted experiments up to maximum power of $3.52 \mathrm{~kW}$ and torque $22.4 \mathrm{~N}-\mathrm{m}$ at $1500 \mathrm{rpm}$. In a conservative study, a comparison of different blends of the same fuel is made; diesel variation is also shown in the same graph 
for comparison purposes. In our study, we have compared the different fuels with the same blends to find the better performing biodiesel. Percentage change in performance of different biodiesel blends concerning diesel as baseline makes it easy to find betterperforming biodiesels. Diesel performance is our base for comparing the performance of the blends. With diesel as a baseline, we compare the performance of the same blends of different fuels.

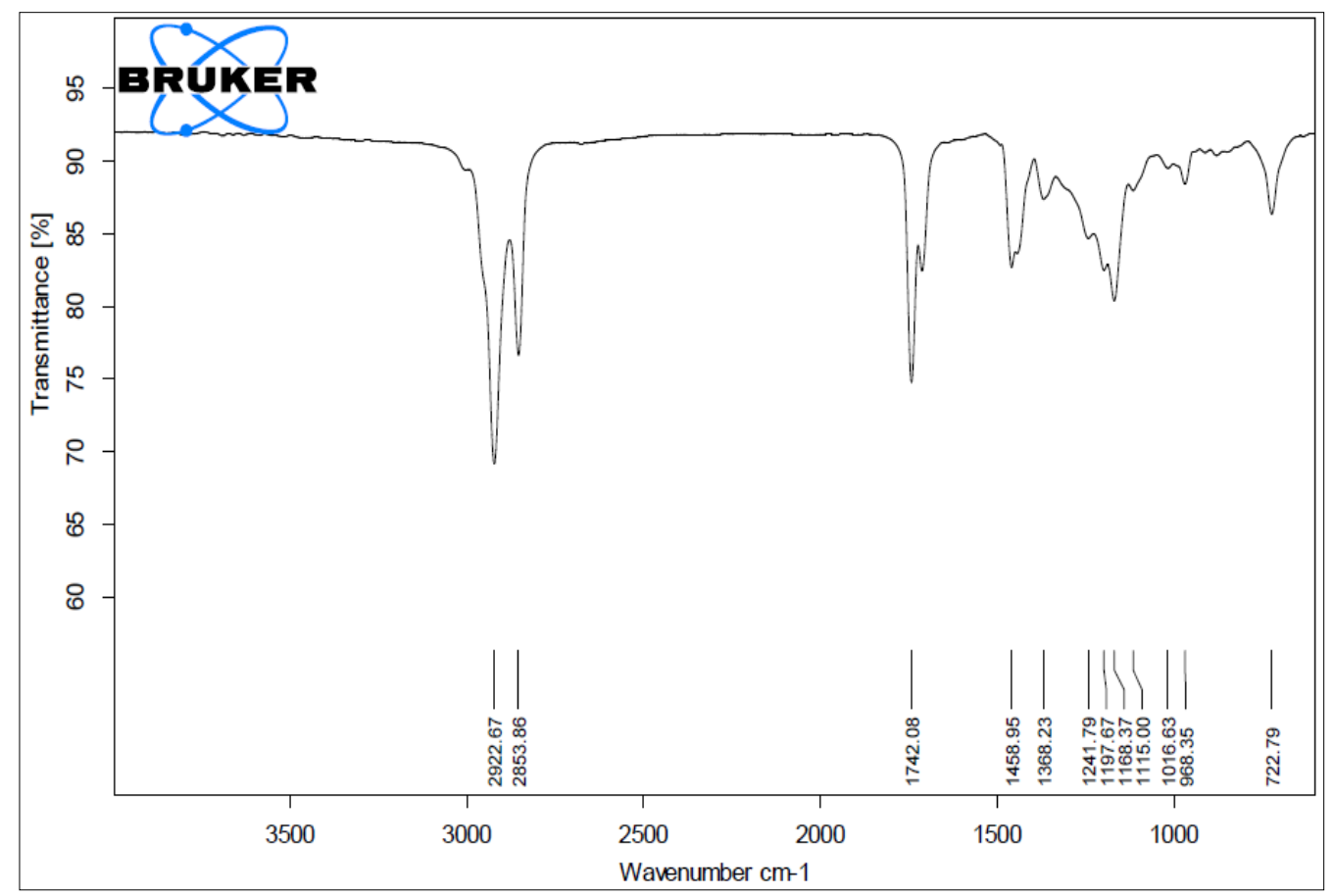

Figure 3. The infrared spectrum of biodiesel from acid oil.

\subsubsection{Brake Thermal Efficiency}

Percentage (\%) change in BTE of the four altered biodiesels of blends B50, B65, B80and B100 compared to diesel are shown in Figures 4-7. The baseline readings of diesel fuel performance in the engine with increasing BP is provided in Appendix A. Initially, at a load condition of $0.588 \mathrm{~kW}$, WC50 blend provided 7.4\% more BTE than diesel, and for increasing load conditions, WC50 combination provided decreasing BTE than diesel fuel. WC50 and CI50 showed BTE closer to diesel engine because of their higher calorific value among the biodiesels used. Because of their higher calorific value, the amount of heat produced was more elevated and there was less difference between diesel, WC50, and CI50. The viscosity of WC50 was lowest, which causes better atomization of fuel hence complete combustion fuel generating more heat and efficient combustion of fuel. AO50 and Honge50 showed a large difference concerning diesel fuel because their lower calorific value and viscosity of these fuels are larger than diesel and other biodiesels. Because of this, the significant decrease in BTE can be seen. Higher viscosity causes improper atomization of fuel droplets being sprayed in the combustion chamber. These fuel droplets remain unburnt hence reducing the BTE. Up to $3.48 \%$ decrease in BTE of WC50 blend was obtained at the highest load condition of $3.5294 \mathrm{~kW}$, as shown in Figure 4. The other biodiesel blends also showed decreasing BTE than diesel for changing loading conditions from $1.174 \mathrm{~kW}$ to $3.5294 \mathrm{~kW}$, as shown in Figure 4. A decrease in BTE by $17 \%$ is obtained for AO50 and the Honge50 blend at the highest loading conditions. This indicates that, at higher operating conditions, biodiesel blends provide lower BTE, which can be considered due to increased surface tension followed by test fuel viscosity nature and reduced volatility of the biodiesel blends. These properties result in improper atomization and deprived spray characteristics. This weak spray property gives rise to improper homogeneity of air-fuel combination, leading to a reduced release of heat from fuel combustion and, therefore, 
lower BTE [33-35]. More unexpectedly, the WC65 blend has shown the lowest BTE of $9.64 \%$ at low load condition, whereas WC50 has demonstrated the highest BTE of 7.4\%, WC 85 and WC100 blends have shown less change in BTE (7.05\% and 7.44\%, respectively) at low load conditions, comparatively (Figures 4-7). WC50 blend has remained the best performer in the change in BTE of the engine compared to $\mathrm{AO} 50$ and Honge50 at all loading conditions except at $2.9411 \mathrm{~kW}$. From the initial load to $1.7647 \mathrm{~kW}$ of capacity, the CI50 blend has poor performance than the WC50 blend, but later on, for the next higher level of loads, CI50 is seen to provide better BTE than WC50. At higher load conditions from $1.1764 \mathrm{~kW}$ to $3.5294 \mathrm{~kW}$, WC65, WC80, and WC100 biodiesel blends have shown poor BTE than diesel, $\mathrm{CI}$, and AO biodiesel. Hence, it can be inferred that, except for the WC50 blend, WC65, WC80, and WC100 provide the least BTE than AO and Honge biodiesel blends.

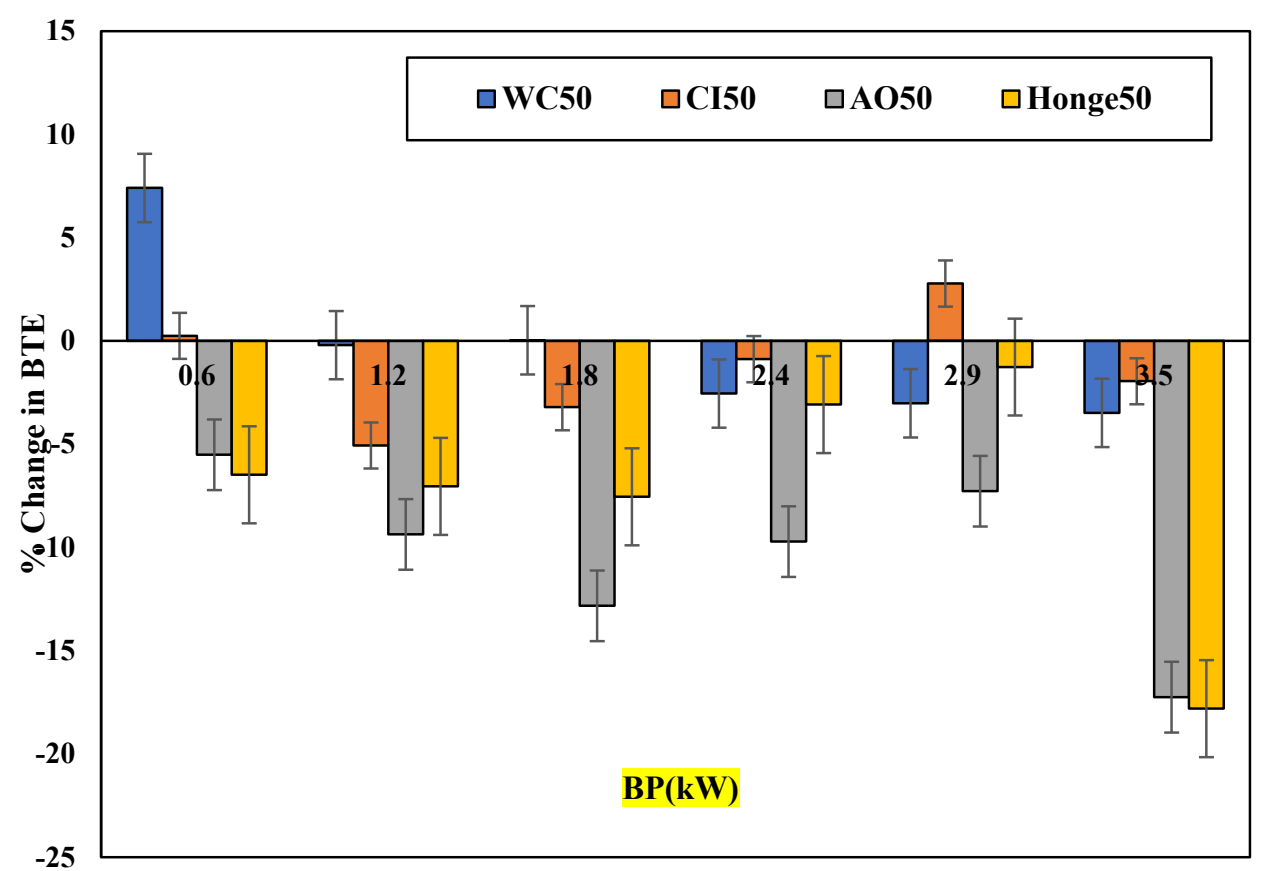

Figure 4. Percentage change in brake thermal efficiency (BTE) of B50 biodiesel compared to diesel.

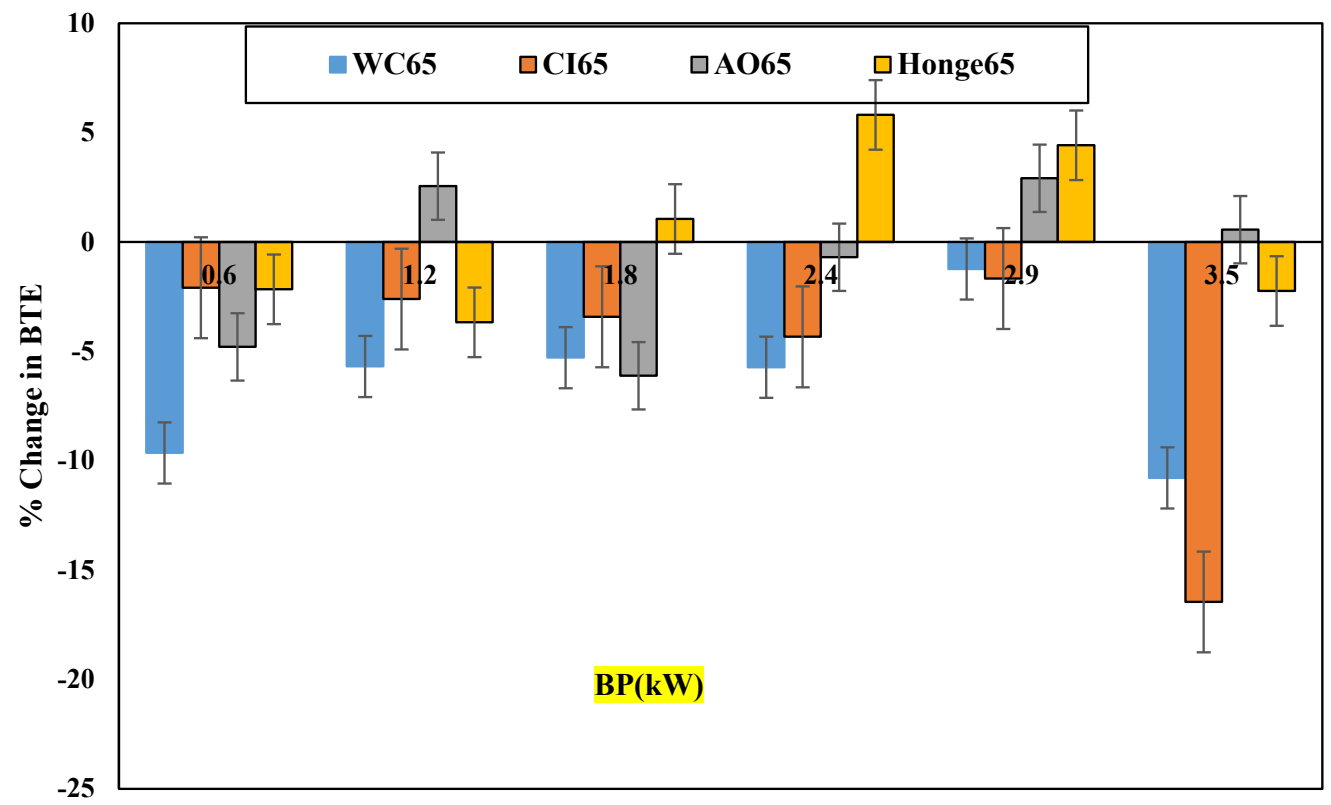

Figure 5. Percentage change in BTE of B65 biodiesel compared to diesel. 


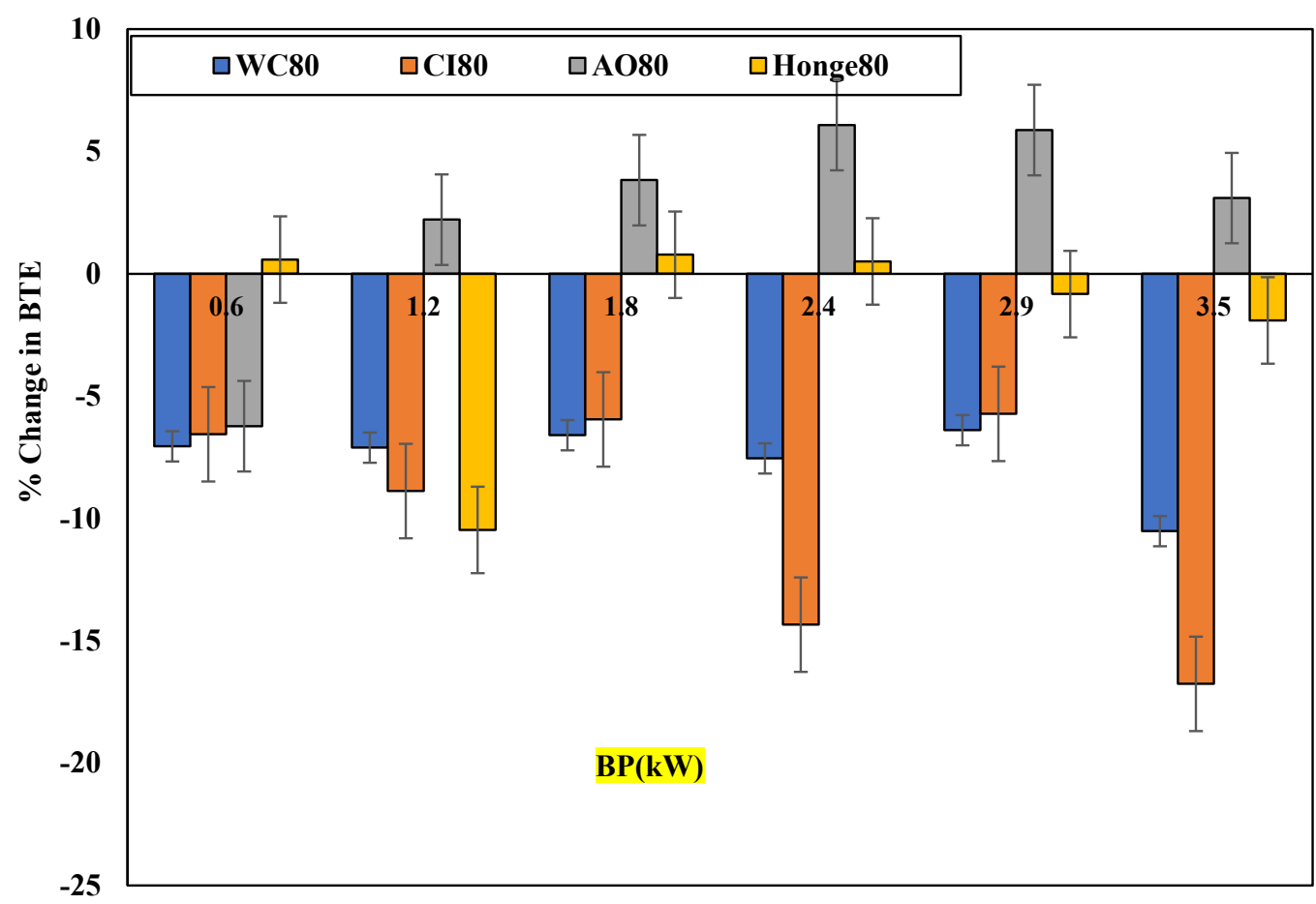

Figure 6. Percentage change in BTE of B80 biodiesel compared to diesel.

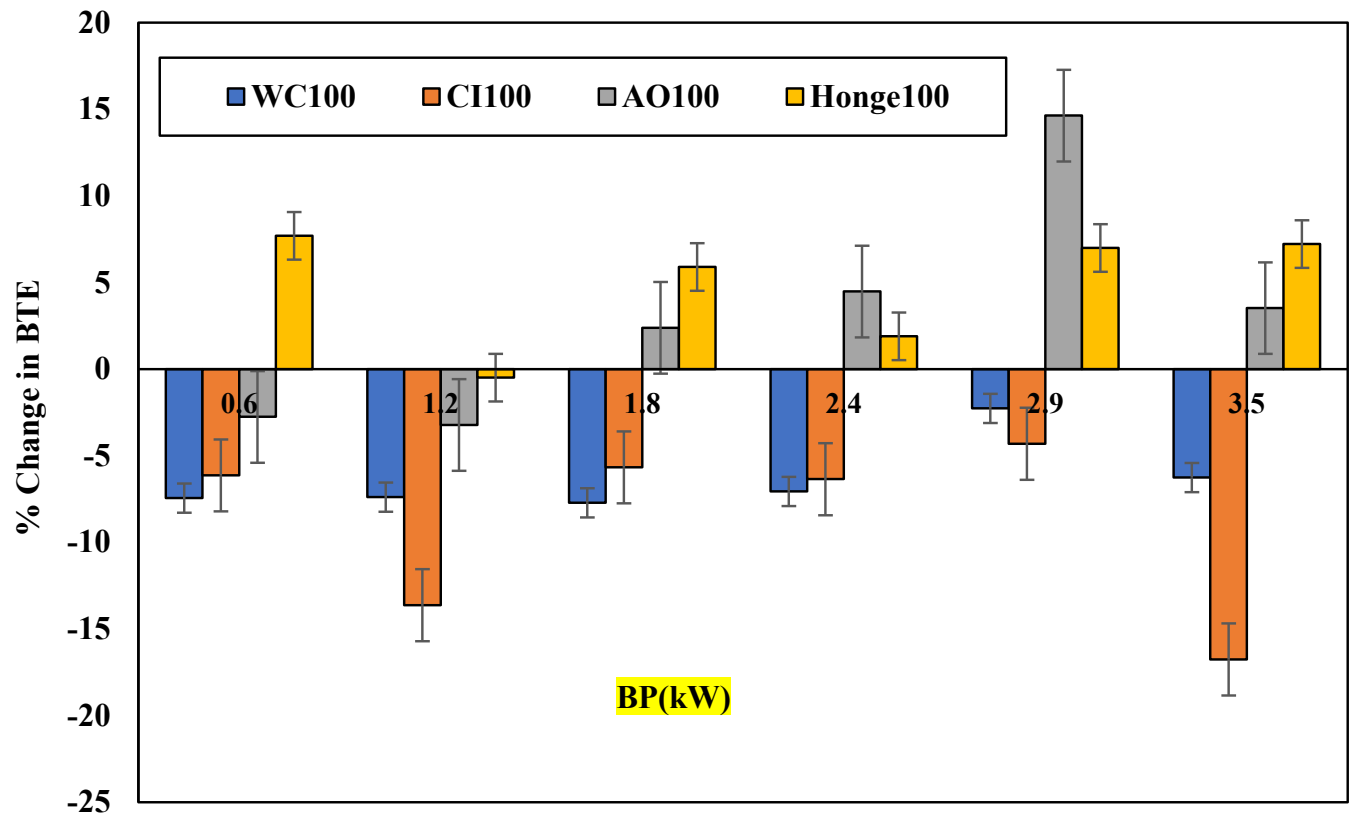

Figure 7. Percentage change in BTE of B100 biodiesel related with petroleum-diesel.

Except at $1.174 \mathrm{~kW}$ of load, the CI50 blend provides BTE close to diesel at all loading conditions, as depicted in Figure 4. CI80 has shown the lowest BTE equal to 16.75\% less than diesel at the highest load condition, which is comparatively the lowest BTE obtained from the entire range of biodiesels and blends considered. CI65 follows CI80, with a slightly better BTE of $16.45 \%$ less than diesel at a maximum load condition of $3.5294 \mathrm{~kW}$, as shown in Figures 5 and 6. CI65 provided less reduction in BTE than WC65 up to $2.3529 \mathrm{~kW}$ load, but at $2.9411 \mathrm{~kW}$ and $3.5294 \mathrm{~kW}$ provided $0.44 \%$ and $5.7 \%$ more reduction in BTE than WC65. CI80 and CI100 have provided more reduction in BTE than WC80 and WC100 at all loading conditions. Figure 4 shows that AO50 and Honge 50 biodiesel provided the lowest BTE at all loads compared to WC50 and CI50. However, higher blends of AO and 
Honge provided the highest BTE compared to higher blends of WC and CI at the entire load showed in Figures 5-7. From this analysis, it is clear that higher blends of WC and CI provide poorer BTE than $\mathrm{AO}$ and Honge blends compared to diesel. Among the higher blends of $\mathrm{CI}$ and WC, CI blends offered lower BTE than WC, whereas only WC50 provides reduced BTE than CI50 at higher loads. Therefore, higher blends of CI are chosen as the most inferior BTE provider, whereas a lower blend of $\mathrm{AO}$ and Honge is considered the least BTE provider. Further analysis in BSFC, BSEC, and EGT will provide a clear idea regarding the best biodiesel blend among the different biodiesel blends considered.

\subsubsection{Brake-Specific Fuel Consumption (BSFC)}

Percentage variation BSFC of biodiesel blends (B50, B65, B80, and B100) concerning diesel (baseline) are calculated and presented in Figures 8-11. Attributable to the minimal calorific value, more fuel density (hence increased bulk modulus), and high viscosity of biodiesels than mineral diesel (Table 2), all the blends of biodiesels show a high rate of fuel intake to produce the equivalent amount of BP as produced by mineral diesel $[20,35]$. The increased bulk modulus of biodiesel leads to more injection (discharge) of the considered biodiesel blend in the combustion chamber for the same amount of displacement of the piston inside the cylinder obtained to the mineral diesel. This shows that more quantity of biodiesel is mandatory to yield the matching $\mathrm{BP}$ value, which is produced by diesel alone. The trend of increase in consumption of biodiesel (BSFC) keeps increasing as the loading conditions increase. As high as $30.5 \%$ and $30 \%$ more BSFC is required at high loading conditions were related to mineral diesel, as shown in Figures 8 and 9. Comparatively, blends of high concentrations (B80 and B100) have shown less BSFC than low concentration blends of B50 and B65 concerning diesel.

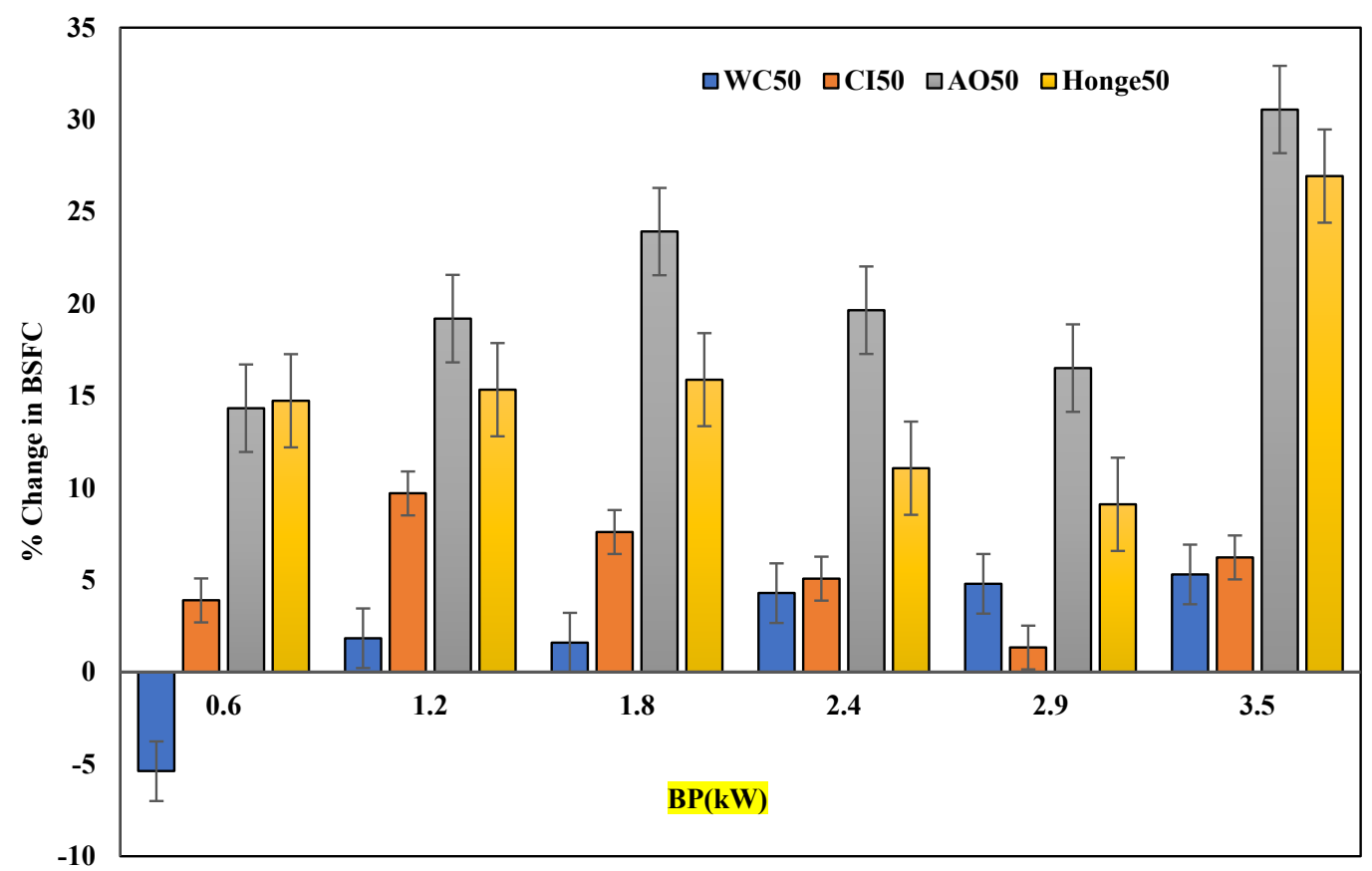

Figure 8. Percentage change of B50 blends for brake-specific fuel consumption (BSFC) compared to diesel. 


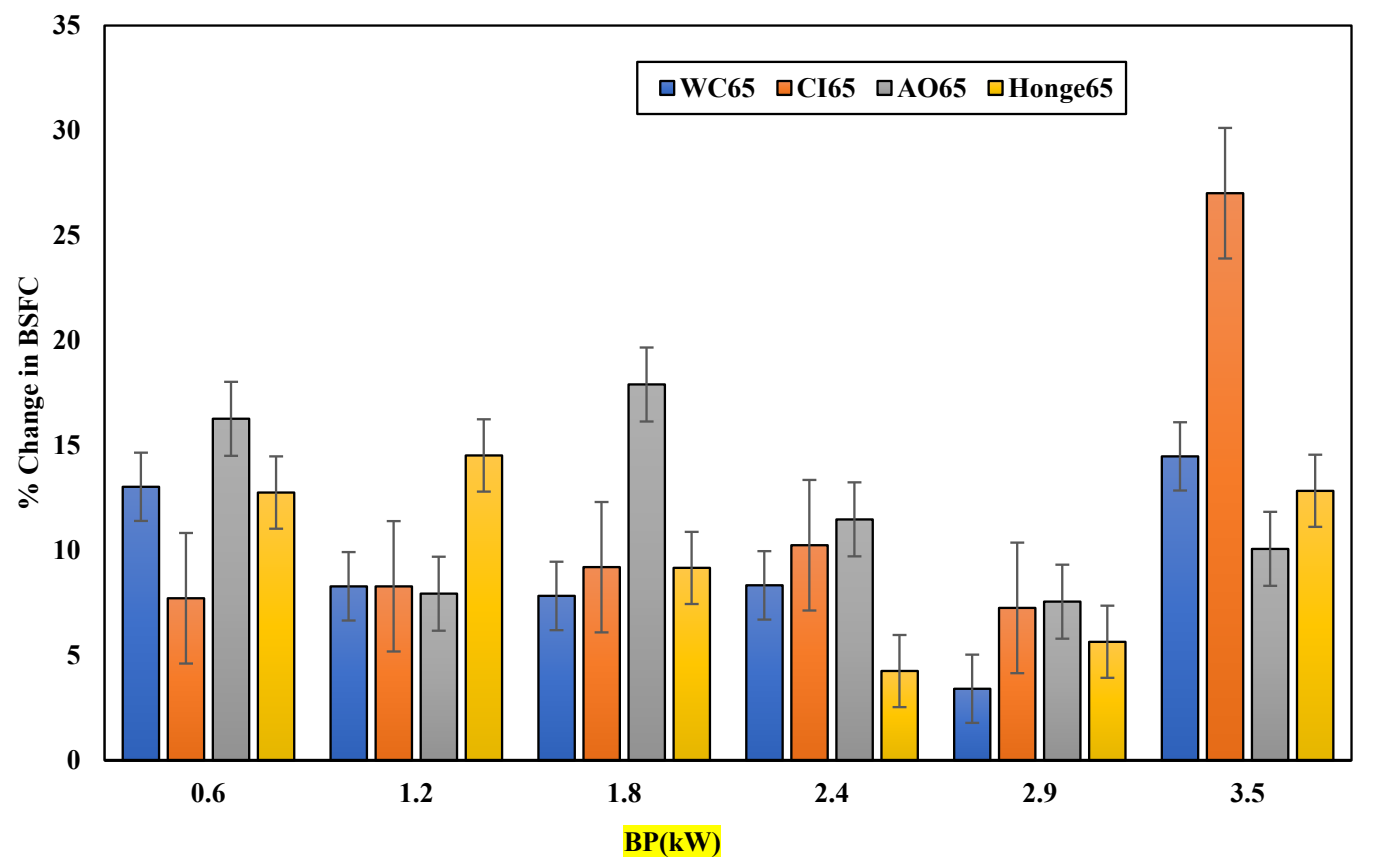

Figure 9. Percentage change of B65 blends for BSFC compared to diesel.

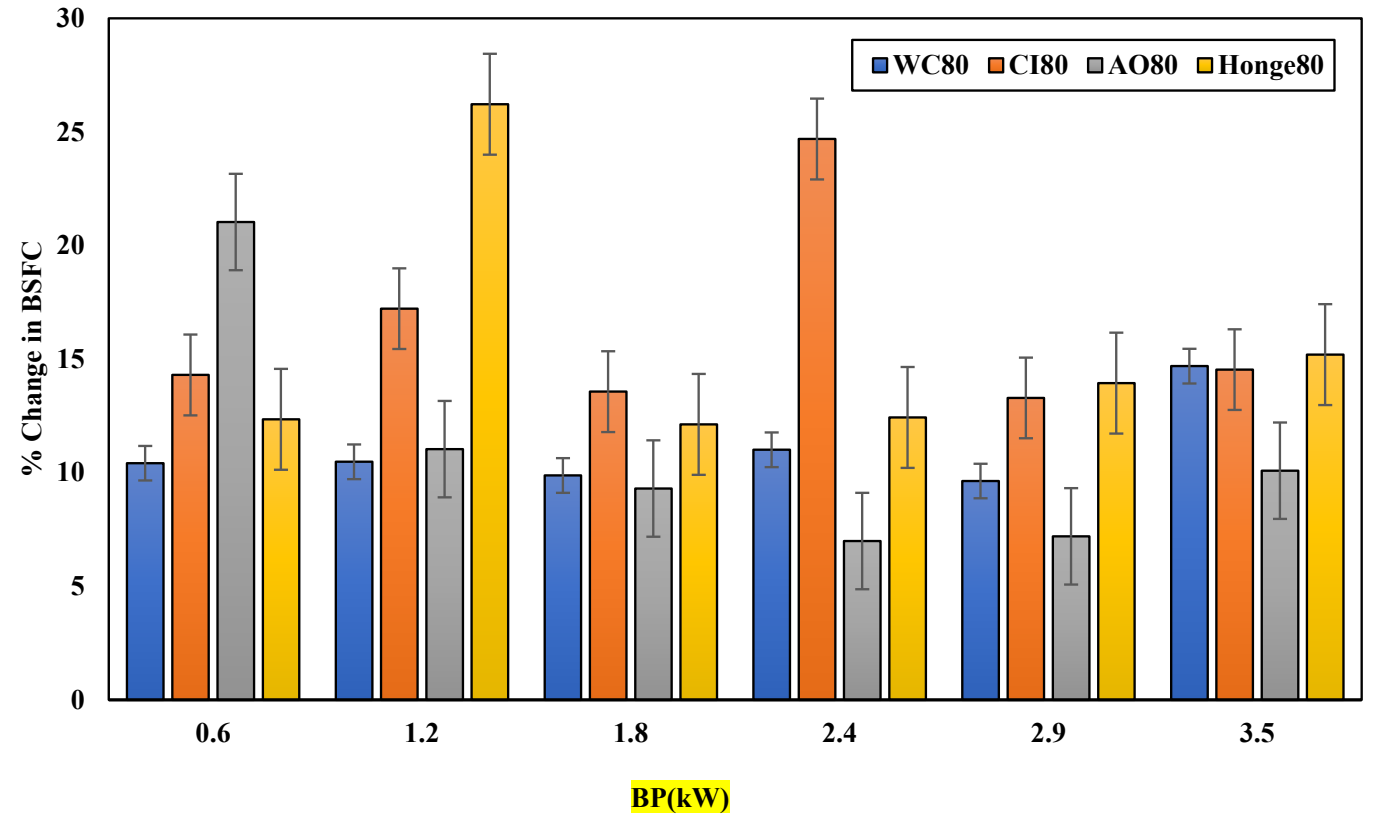

Figure 10. Percentage change of B80 blends for BSFC compared to diesel.

CI50, AO50, and Honge50 blends show a very similar trend for variation in BSFC at entire load conditions, whereas BSFC by WC50 blend remains increasing along with an increase in load, as shown in Figure 8. B65 blends show a meager increase in BFSC required at a load condition of $2.9411 \mathrm{~kW}$ compared to other loading conditions. Only CI65 shows more BSFC needed at the highest load condition (Figure 9), whereas different biodiesel blends of $\mathrm{B} 65$ remain in the same range at all load conditions. For B80 blends, an average of $14 \%$ increase in BSFC is observed at all loading conditions, as shown in Figure 10. Honge80 has demonstrated the highest BSFC (26.2\%) required at a load of $1.1764 \mathrm{~kW}$, whereas CI80 has been shown the highest increase in BFSC by $24.6 \%$ at a capacity of $1.7647 \mathrm{~kW}$. At a load condition of $2.9411 \mathrm{~kW}$, B100 blends of all biodiesels considered have shown the least increase in BSFC, as shown in Figure 11. More BSFC is required for a load of $1.1764 \mathrm{~kW}$ by all biodiesels of B100 compared to diesel, and only CI100 consumes the highest BSFC at the 
most elevated load conditions. AO100 needed only 2.4\% more BSFC than diesel at a load of $2.9411 \mathrm{~kW}$ related with entire B100 blends at peak load.

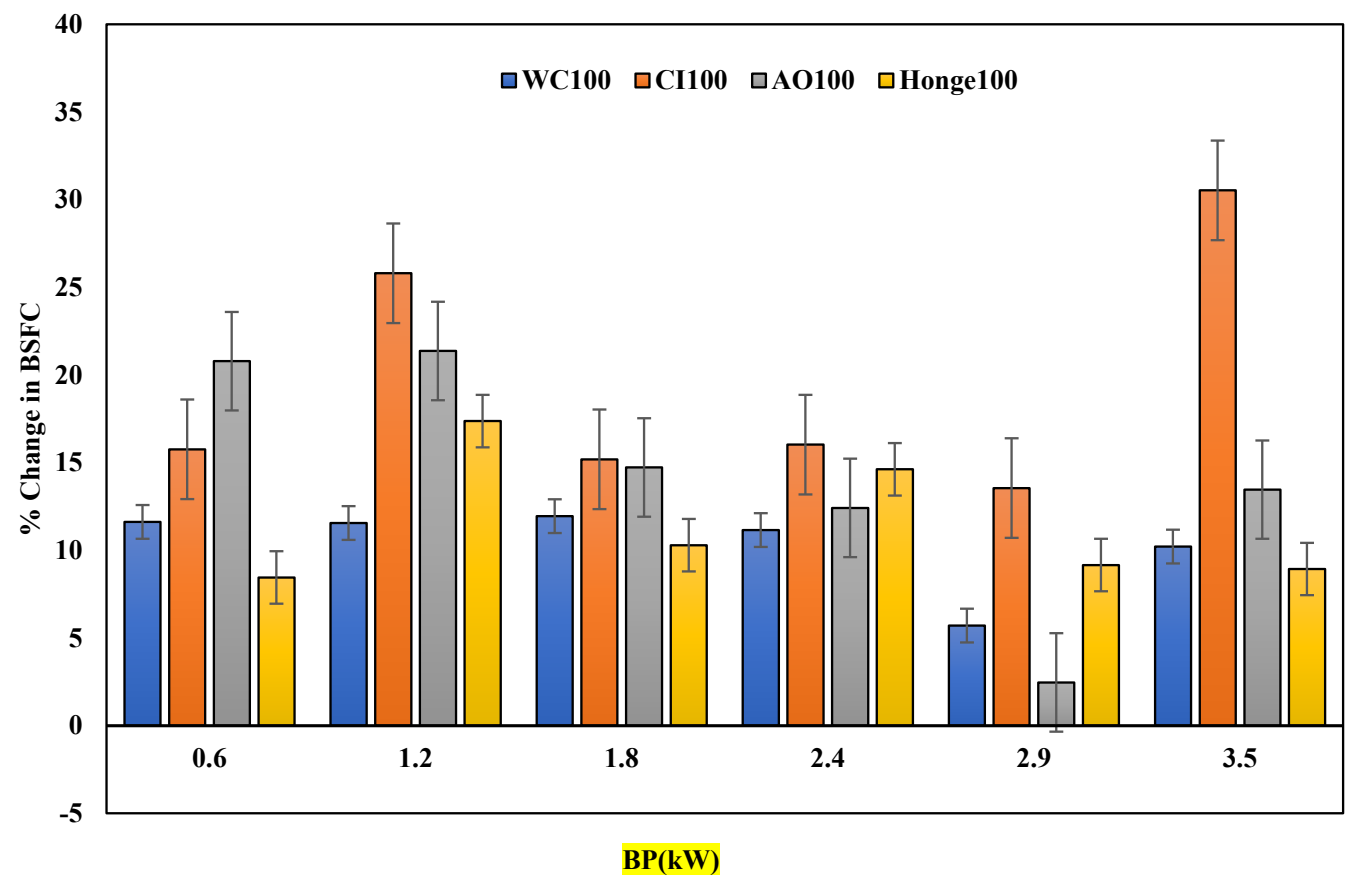

Figure 11. Percentage change of B100 blends for BSFC related with petroleum-diesel.

WC50 and CI50 showed the lowest BSFC compared to other biodiesels and lower variation compared to diesel. Because of their lower viscosity which causes better atomization of fuel and efficient combustion, the BSFC was closer to diesel fuel, and fuel required per kW of energy production was lower. Calorific value of WC50 and CI50 is higher than other biodiesels; hence, fuel required per $\mathrm{kW}$ is lower. AO50 and Honge50 showed higher BSFC because of their lower calorific value, which requires a larger mass of fuel per $\mathrm{kW}$ of power generation, which requires a larger mass of fuel per $\mathrm{kW}$ of power generation larger BSFC values. AO50 and Honge 50 showed higher viscosity which is also the reason for higher BSFC values because high viscosity causes incomplete combustion as higher viscosities cause larger fuel droplets and incomplete combustion. Incomplete combustion leads to higher fuel requirement per $\mathrm{kW}$ of power generation. WC50 shows the least percentage upstream in BSFC at the entire load related with CI50, AO50, and Honge50. WC50 is followed by CI50 with a slight increase in BSFC, as shown in Figure 9 at all loading conditions. At $0.588 \mathrm{KW}$ load, WC50 provided 5.37\% less BSFC than diesel, and at $3.5294 \mathrm{KW}$, WC50 showed a high BSFC increase by $5.3 \%$ compared to other loading conditions for the same blend. This indicates that BSFC reached the highest for WC50 at the highest load, and the same is true for different biodiesel blends of B50. AO50 needed the highest BSFC at entire loading conditions related to additional B50 blends. Honge50 followed the top BSFC trend of AO50 at all loading conditions. WC65 required more BSFC than CI65 and Honge65 at lower loads, whereas it needed less BSFC than CI65 at higher loads of $2.9411 \mathrm{~kW}$ and $3.5294 \mathrm{~kW}$. AO65 at all loads needed the highest BSFC, but at the highest load needed lowest BSFC than other biodiesel blends, which are exceptional.

WC 80 was almost in the same range of around $12 \%$ increase in BSFC than diesel at all loadings. AO80 showed the highest BSFC, about $21.03 \%$ at only $0.588 \mathrm{~kW}$ load, and all other loads remained better than WC80, CI80, and Honge80, as shown in Figure 10. Honge 80 provided the highest peak at $1.7647 \mathrm{~kW}$ and $\mathrm{CI} 80$ at $2.9411 \mathrm{~kW}$, and other loading conditions remained close to $14 \%$. WC100 maintained a marginal increment in BSFC of $11 \%$ related to mineral diesel at all loads, as exemplified in Figure 11. From Figure 11, we can infer that CI100 requires the highest BSFC at all loadings that were related to other biodiesel blends except minimal load condition. Similarly, AO100 has the second-highest 
BSFC increase at all loading conditions. Honge100 has shown better BSFC performer than WC100 at the lowest and highest loadings.

From this analysis, it can be understood that WC50, WC80, and WC100 have performed better in BSFC \%increase than the result of the biodiesel blends at entire loading environments. Honge 65 would be considered comparatively better than all $\mathrm{B} 65$ biodiesel blends at all loadings. AO50 required the highest increase in BSFC at all loads compared to all $\mathrm{B} 50$ blends, and $\mathrm{AO} 80$ and $\mathrm{AO} 100$ required less BSFC than B80 and B100 blends of CI and Honge. Increase in BSFC by CI was best only at a mix of B50 (i.e., CI50) and then at higher blends (CI65, CI80, and CI100) remained the highest increase in BSFC at different loading conditions.

\subsubsection{Exhaust Gas Temperature (EGT) Analysis}

EGT for all biodiesel fuel blends shows a pervasive nature of variation for different loading conditions, which can be easily predicted from Figures 12-15. Percentage change variation regarding diesel is calculated, and the unit of temperature was centigrade. The EGT increase can be seen from the initial load to $2.4 \mathrm{~kW}$ of load for all blends. EGT thereon further reduced for an increase in load. The high viscosity and reduced volatility result in improper spraying of biodiesel into the combustion chamber. Adding to this, the slow combustion owing to peak fuel viscosity of the biodiesel yields more amount of heat released at the later stage of the power stroke, which does not get converted into work but appears as high heat in exhaust gases. This also produced deduced thermal efficiency of the diesel engine [36-39].

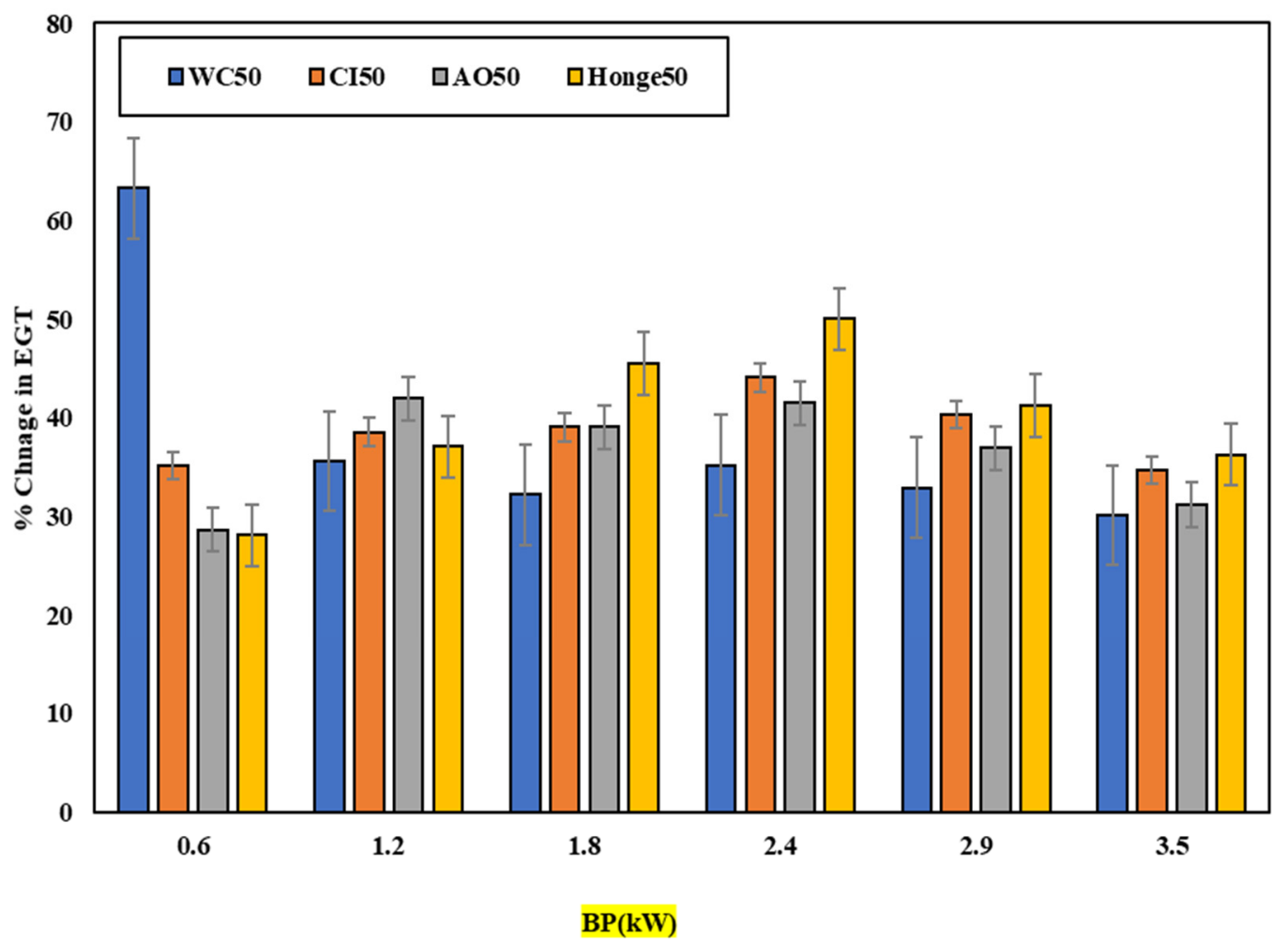

Figure 12. Percentage change in exhaust gas temperature (EGT) of B50 biodiesel blend. 


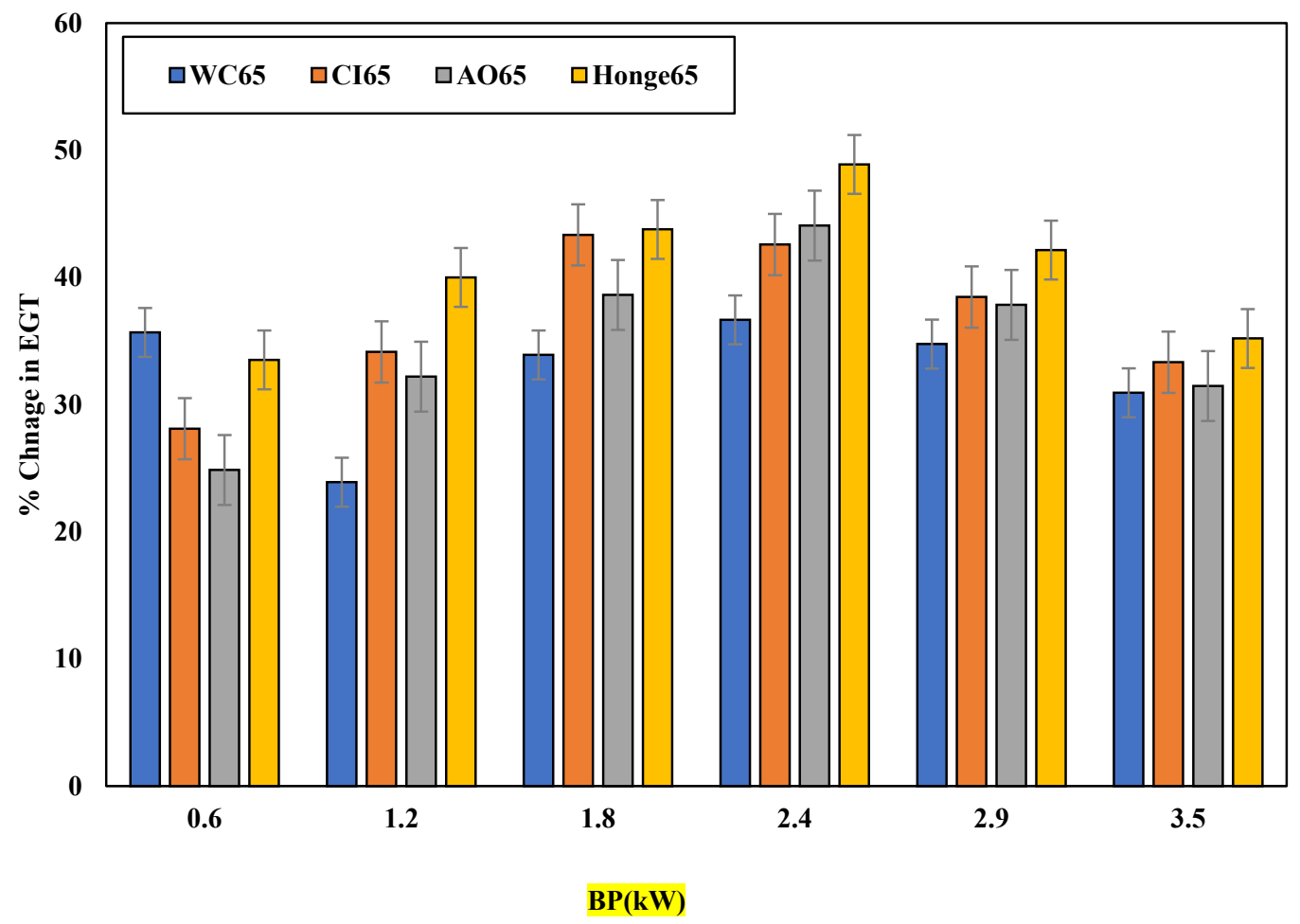

Figure 13. Percentage change in EGT of B65 biodiesel blend.

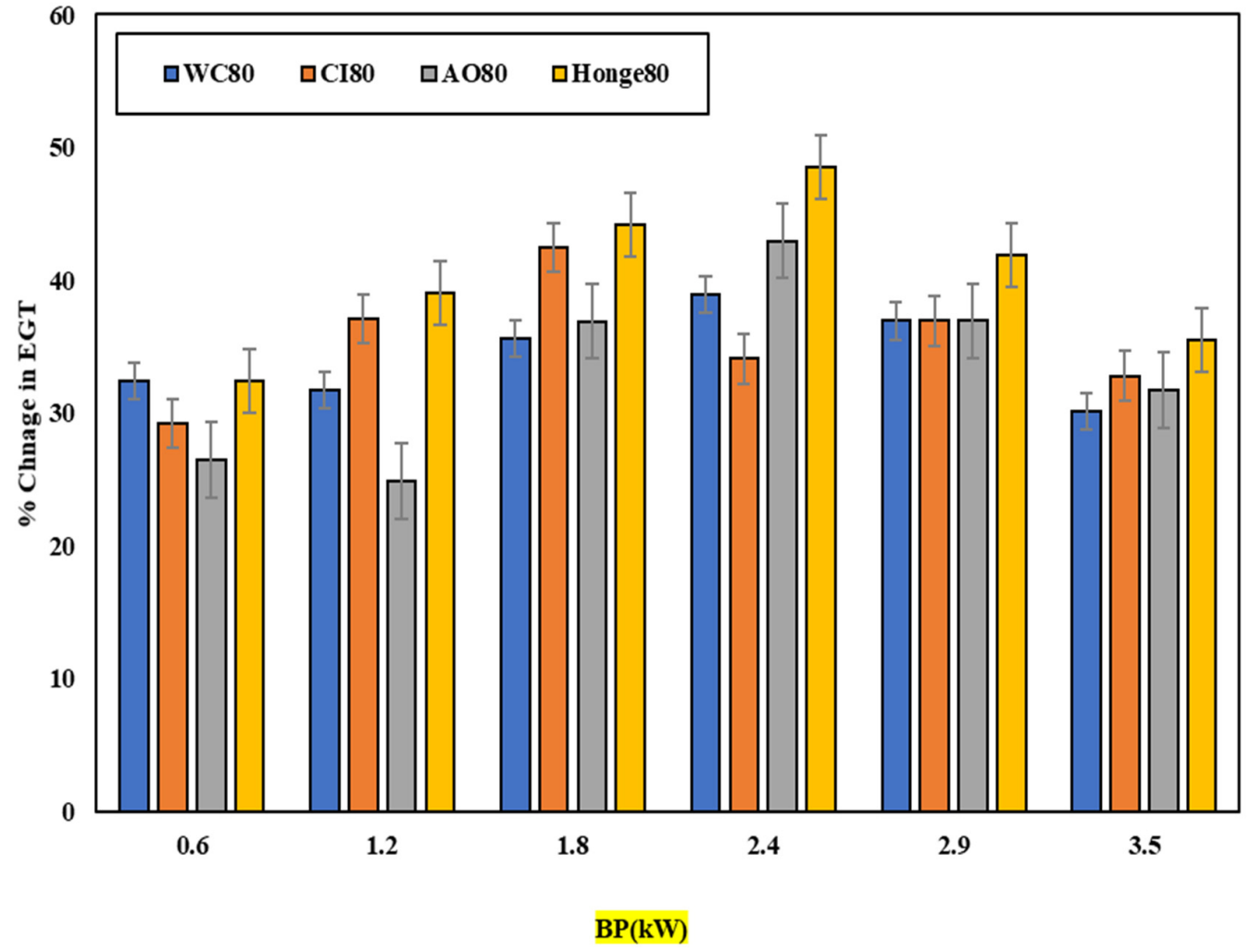

Figure 14. Percentage change in EGT of B80 biodiesel blend. 


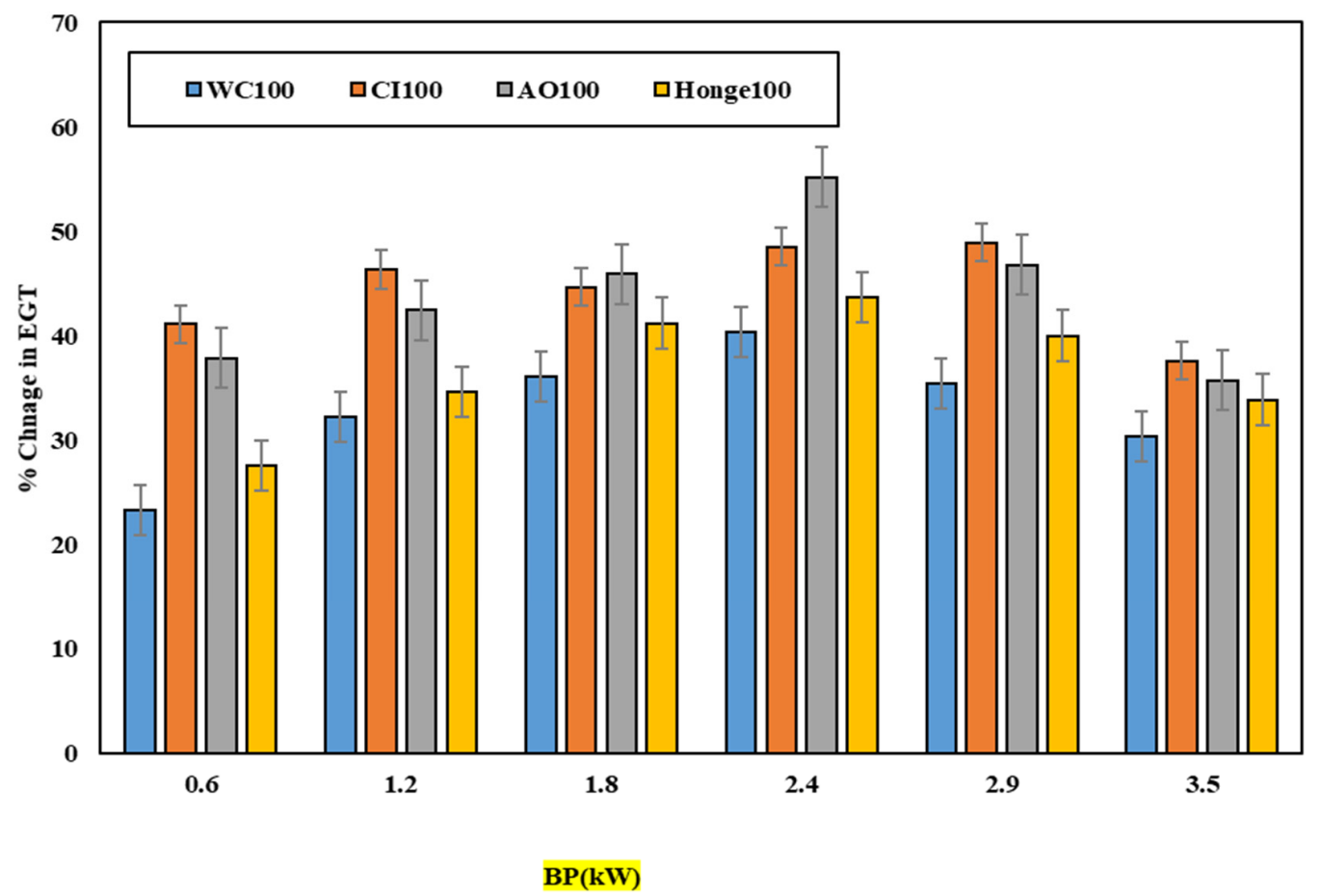

Figure 15. Percentage change in EGT of B100 biodiesel blend.

From Figure 12, it can be seen that all biodiesels have higher exhaust gas temperatures compared to diesel. A lower EGT indicates complete combustion of fuel and lower heat loss. Higher temperatures are indicative of inefficient usage of thermal energy from fuel. Diesel, which is baseline here, has lower EGT temperature because it has higher calorific value and, lower viscosity and density lead to complete combustion of fuel. Among biodiesels CI50, AO50 and Honge50 have higher viscosities and densities, which cause higher exhaust gas temperature due to poor atomization, and in turn leads to incomplete combustion and after burning. Higher EGT of biodiesel is also due to inherent oxygen content. The similar pattern of trend can be seen for other blends of biodiesels. As diesel has a higher cetane number, which causes lower ignition delay hence earlier start of combustion and shorter power cycle therefore reducing EGT $[40,41]$. The blend B65, B80, and B100 having highly non-linear pattern is depicted in Figure 13, Figure 14, and Figure 15 respectively as explained further. In Figure 13 the trend followed is by B85 blend id somewhat similar to the nature of B50 blend. However, B80 and B100 behave totally different.

The highest EGT increase obtained for biodiesel is $55.1 \%$ (Figure 15) at $2.4 \mathrm{~kW}$ of load, and the lowest rise in EGT is $23.24 \%$ (Figure 14) at the lowest load conditions. For blends of B50, B65 and B80, Honge biodiesel has shown the highest increase in EGT at all the higher loads, as shown in Figures 13-15, whereas for blend B100, AO100, and CI100 have shown highest EGT at higher loading conditions comparatively (refer Figure 14). Overall, WC blends remain the lowest increase in EGT for almost all circumstances. Honge50 and Honge65 provided excessive EGT than other biodiesels of B50, and B65 blends at higher loads. Honge80, at all loads, has more EGT than all B80 blends with a maximum difference of $10 \%$.

\section{Conclusions}

This experimental study on different biodiesels of higher blends was performed in various phases. At the initial stage, four altered biodiesels were produced from four different sources (AO: acid oil, CI: Calophyllum inophyllum, PP: Pongamia pinnata, also known as Honge, and WCO: waste cooking oil) was prepared by the trans-esterification method. Biodiesels produced were tested for their physicochemical properties and compared with diesel. The engine performance test was carried out for these biodiesels of higher con- 
centration (B50, B65, B80, and B100) and which result was related with mineral diesel its detailed inferences as follows: Density of the acid oil and WC oil was found to be lowest, but closer to the diesel compared to other biodiesels. The calorific value of CI and WC oil was found to be the highest, making it a better fuel closer to the value of diesel. The important conclusion drawn from the present study are as follows:

- The performance of acid oil blend B50 was the bio-fuel which provided enhanced brake thermal efficiency (BTE) compared to diesel at higher loads due to superior combustion wherein the cylinder temperature is higher.

- Honge oil at B50 blend did not perform well at any load. However, with the \% increase of blend, the Honge oil started showing improved BTE than other oils. At B100, the BTE was superior to diesel fuel.

- Calophyllum inophyllum did not provide any acceptable BTE with increasing load. It was biodiesel with the lowest thermal efficiency.

- In comparison with entire biodiesels, B50 blends of WC oil and CI have provided the lowest brake-specific fuel consumption (BSFC) at all loads. However, at higher loads, a high BSFC was related to mineral diesel for all biodiesels.

- EGT of all biodiesels was lower for B50 blends and increased with biodiesel content blends. For higher loads, EGT was seen to be reduced compared to lower load conditions.

- Waste cooking oil at B50 showed high energy losses due to unutilized bio-diesel energy indicated by the increased EGT. However, an increase in blend content slightly reduced the EGT from the engine.

- Acid oil showed very high EGT from the engine when it was fully used as fuel for the diesel engine. But this EGT was reduced consistently with other blends as well with increasing engine brake power.

- Honge oil, on the other hand, has provided higher EGTs at any load compared to other biodiesel used in this study. But the trend of falling EGT with increasing load was common with other biodiesel also.

Author Contributions: Conceptualization, A.A. and S.A.; Formal analysis, A.B., R.S., N.H. and A.S.C.; Investigation, R.S.; Methodology, M.E.M.S.; Resources, M.A.M.; Software, M.K.; Validation, F.Q.; Writing—original draft, A.A. and M.E.M.S.; Writing—review \& editing, N.H. All authors have read and agreed to the published version of the manuscript.

Funding: Deanship of Scientific Research at King Khalid University, grant no. R.G.P.1/132/42.

Institutional Review Board Statement: Not applicable.

Informed Consent Statement: Not applicable.

Data Availability Statement: Not applicable.

Acknowledgments: The authors extend their appreciation to the Deanship of Scientific Research at King Khalid University, Saudi Arabia, to fund this work through the Research Group Program under Grant No: R.G.P.1/132/42.

Conflicts of Interest: The authors declare no conflict of interest. 


\section{Appendix A}

Table A1. Diesel engine readings for different BP as baseline for comparison with BTE, BFSC, and EGT of biodiesels.

\begin{tabular}{cccc}
\hline BP kW & BTE $(\%)$ & BSFC $(\mathbf{k g} / \mathbf{k W}-\mathbf{h})$ & EGT $\left({ }^{\circ} \mathbf{C}\right)$ \\
\hline 0.6 & 7.834444 & 1.081198437 & 210 \\
1.2 & 14.00675 & 0.604750571 & 250 \\
1.8 & 18.0097 & 0.470334901 & 280 \\
2.4 & 20.67751 & 0.40965233 & 310 \\
2.9 & 21.67785 & 0.390748621 & 350 \\
3.5 & 23.01239 & 0.368088183 & 390 \\
\hline
\end{tabular}

\section{References}

1. Soudagar, M.; Afzal, A.; Kareemullah, M. Waste coconut oil methyl ester with and without additives as an alternative fuel in diesel engine at two different injection pressures. Energy Sources Part A Recovery Util. Environ. Eff. 2020, 1-9. [CrossRef]

2. Soudagar, M.E.M.; Mujtaba, M.; Safaei, M.R.; Afzal, A.; Ahmed, W.; Banapurmath, N.; Hossain, N.; Bashir, S.; Badruddin, I.A.; Goodarzi, M. Effect of Sr@ ZnO nanoparticles and Ricinus communis biodiesel-diesel fuel blends on modified CRDI diesel engine characteristics. Energy 2020, 215, 119094. [CrossRef]

3. Marikatti, M.; Banapurmath, N.; Yaliwal, V.; Basavarajappa, Y.; Soudagar, M.E.M.; Márquez, F.P.G.; Mujtaba, M.; Fayaz, H.; Naik, B.; Khan, T. Hydrogen injection in a dual fuel engine fueled with low-pressure injection of methyl ester of thevetia peruviana (METP) for diesel engine maintenance application. Energies 2020, 13, 5663. [CrossRef]

4. Hossain, N.; Mahlia, T.; Saidur, R. Latest development in microalgae-biofuel production with nano-additives. Biotechnol. Biofuels 2019, 12, 125. [CrossRef]

5. Hossain, N.; Mahlia, T.M.I.; Miskat, M.; Chowdhury, T.; Barua, P.; Chowdhury, H.; Nizamuddin, S.; Ahmad, N.B.; Zaharin, N.A.B.; Mazari, S.A.; et al. Bioethanol Production from Forest Residues and Life Cycle Cost Analysis of Bioethanol-Gasoline Blend on Transportation Sector. J. Environ. Chem. Eng. 2021, 9, 105542. [CrossRef]

6. Mahlia, T.M.I.; Ismail, N.; Hossain, N.; Silitonga, A.S. Palm oil and its wastes as bioenergy sources: A comprehensive review. Environ. Sci. Pollut. Res. 2019, 26, 14849-14866. [CrossRef] [PubMed]

7. S Savhane, R.; M Kate, A.; Pawar, A.; Safaei, M.R.; M Soudagar, M.E.; Mujtaba Abbas, M.; Muhammad Ali, H.; R Banapurmath, N.; Goodarzi, M.; Badruddin, I.A. Effect of zinc oxide nano-additives and soybean biodiesel at varying loads and compression ratios on VCR diesel engine characteristics. Symmetry 2020, 12, 1042. [CrossRef]

8. Razzaq, L.; Mujtaba, M.; Soudagar, M.E.M.; Ahmed, W.; Fayaz, H.; Bashir, S.; Fattah, I.R.; Ong, H.C.; Shahapurkar, K.; Afzal, A. Engine performance and emission characteristics of palm biodiesel blends with graphene oxide nanoplatelets and dimethyl carbonate additives. J. Environ. Manag. 2021, 282, 111917. [CrossRef]

9. Soudagar, M.E.M.; Banapurmath, N.; Afzal, A.; Hossain, N.; Abbas, M.M.; Haniffa, M.A.C.M.; Naik, B.; Ahmed, W.; Nizamuddin, S.; Mubarak, N. Study of diesel engine characteristics by adding nanosized zinc oxide and diethyl ether additives in Mahua biodiesel-diesel fuel blend. Sci. Rep. 2020, 10, 15326. [CrossRef]

10. Venu, H.; Raju, V.D.; Lingesan, S.; Soudagar, M.E.M. Influence of Al2O3nano additives in ternary fuel (diesel-biodiesel-ethanol) blends operated in a single cylinder diesel engine: Performance, Combustion and Emission Characteristics. Energy 2020, 215, 119091. [CrossRef]

11. Khan, H.; Soudagar, M.E.M.; Kumar, R.H.; Safaei, M.R.; Farooq, M.; Khidmatgar, A.; Banapurmath, N.R.; Farade, R.A.; Abbas, M.M.; Afzal, A. Effect of Nano-Graphene Oxide and n-Butanol Fuel Additives Blended with Diesel-Nigella sativa Biodiesel Fuel Emulsion on Diesel Engine Characteristics. Symmetry 2020, 12, 961. [CrossRef]

12. Mujtaba, M.; Cho, H.M.; Masjuki, H.; Kalam, M.; Farooq, M.; Soudagar, M.E.M.; Gul, M.; Afzal, A.; Ahmed, W.; Raza, A. Effect of primary and secondary alcohols as oxygenated additives on the performance and emission characteristics of diesel engine. Energy Rep. 2021, 7, 1116-1124. [CrossRef]

13. Savariraj, S.; Ganapathy, T.; Saravanan, C. Performance and emission characteristics of diesel engine using high-viscous vegetable oil. Int. J. Ambient Energy 2012, 33, 193-203. [CrossRef]

14. Soudagar, M.E.M.; Nik-Ghazali, N.-N.; Kalam, M.; Badruddin, I.A.; Banapurmath, N.; Ali, M.A.B.; Kamangar, S.; Cho, H.M.; Akram, N. An investigation on the influence of aluminium oxide nano-additive and honge oil methyl ester on engine performance, combustion and emission characteristics. Renew. Energy 2020, 146, 2291-2307. [CrossRef]

15. Sahoo, P.; Das, L.; Babu, M.; Naik, S. Biodiesel development from high acid value polanga seed oil and performance evaluation in a CI engine. Fuel 2007, 86, 448-454. [CrossRef]

16. Sahoo, P.; Das, L.; Babu, M.; Arora, P.; Singh, V.; Kumar, N.; Varyani, T. Comparative evaluation of performance and emission characteristics of Jatropha, karanja and polanga based biodiesel as fuel in a tractor engine. Fuel 2009, 88, 1698-1707. [CrossRef]

17. Ong, H.C.; Masjuki, H.; Mahlia, T.I.; Silitonga, A.; Chong, W.; Yusaf, T. Engine performance and emissions using Jatropha curcas, Ceiba pentandra and Calophyllum inophyllum biodiesel in a CI diesel engine. Energy 2014, 69, 427-445. [CrossRef] 
18. Fattah, I.R.; Masjuki, H.; Kalam, M.; Wakil, M.; Ashraful, A.; Shahir, S.A. Experimental investigation of performance and regulated emissions of a diesel engine with Calophyllum inophyllum biodiesel blends accompanied by oxidation inhibitors. Energy Convers. Manag. 2014, 83, 232-240. [CrossRef]

19. Sajjad, H.; Masjuki, H.; Varman, M.; Kalam, M.; Arbab, M.; Imtenan, S.; Ashraful, A. Influence of gas-to-liquid (GTL) fuel in the blends of Calophyllum inophyllum biodiesel and diesel: An analysis of combustion-performance-emission characteristics. Energy Convers. Manag. 2015, 97, 42-52. [CrossRef]

20. Rahman, S.A.; Masjuki, H.; Kalam, M.; Abedin, M.; Sanjid, A.; Sajjad, H. Production of palm and Calophyllum inophyllum based biodiesel and investigation of blend performance and exhaust emission in an unmodified diesel engine at high idling conditions. Energy Convers. Manag. 2013, 76, 362-367. [CrossRef]

21. Ong, H.; Mahlia, T.; Masjuki, H.; Norhasyima, R. Comparison of palm oil, Jatropha curcas and Calophyllum inophyllum for biodiesel: A review. Renew. Sustain. Energy Rev. 2011, 15, 3501-3515. [CrossRef]

22. Atabani, A.; da Silva César, A. Calophyllum inophyllum L.-A prospective non-edible biodiesel feedstock. Study of biodiesel production, properties, fatty acid composition, blending and engine performance. Renew. Sustain. Energy Rev. 2014, 37, 644-655. [CrossRef]

23. Hegde, A.K.; Rao, K.S. Performance and emission study of $4 \mathrm{~S} \mathrm{CI}$ engine using calophyllum inophyllum biodiesel with additives. Int. J. Appl. Res. Mech. Eng. 2012, 1, 2319-3182.

24. Hwang, J.; Qi, D.; Jung, Y.; Bae, C. Effect of injection parameters on the combustion and emission characteristics in a common-rail direct injection diesel engine fueled with waste cooking oil biodiesel. Renew. Energy 2014, 63, 9-17. [CrossRef]

25. Kulkarni, B.; Pujar, B.; Shanmukhappa, S. Investigation of Acid Oil as a Source of Biodiesel. 2008. Available online: http: / / nopr.niscair.res.in/bitstream/123456789/2858/1/IJCT\%2015\%285\%29\%20467-471.pdf (accessed on 1 July 2021).

26. Sureshkumar, K.; Velraj, R.; Ganesan, R. Performance and exhaust emission characteristics of a CI engine fueled with Pongamia pinnata methyl ester (PPME) and its blends with diesel. Renew. Energy 2008, 33, 2294-2302. [CrossRef]

27. Bojan, S.; Durairaj, S. Producing biodiesel from high free fatty acid Jatropha curcas oil by a two step method-an Indian case study. J. Sustain. Energy Environ. 2012, 3, 63-66.

28. Christensen, E.; McCormick, R.L. Long-term storage stability of biodiesel and biodiesel blends. Fuel Process. Technol. 2014, 128, 339-348. [CrossRef]

29. Rajesh, S.; Kulkarni, B.; Banapurmath, N.; Kumarappa, S. Effect of injection parameters on performance and emission characteristics of a CRDi diesel engine fuelled with acid oil biodiesel-ethanol blended fuels. Biofuels 2018, 9, 353-367. [CrossRef]

30. Al-Hartomy, O.A.; Mujtaba, M.; Al-Ghamdi, A.; Iqbal, J.; Wageh, S. Combined effect of Phoenix dactylifera biodiesel and multiwalled carbon nanotube-titanium dioxide nanoparticles for modified diesel engines. Int. J. Environ. Sci. Technol. 2021. [CrossRef]

31. Popovicheva, O.B.; Kireeva, E.D.; Steiner, S.; Rothen-Rutishauser, B.; Persiantseva, N.M.; Timofeev, M.A.; Shonija, N.K.; Comte, P.; Czerwinski, J. Microstructure and chemical composition of diesel and biodiesel particle exhaust. Aerosol Air Qual. Res. 2014, 14, 1392-1401. [CrossRef]

32. O'Donnell, S.; Demshemino, I.; Yahaya, M.; Nwandike, I.; Okoro, L. A review on the spectroscopic analyses of biodiesel. Eur. Int. J. Sci. Technol. 2013, 2, 137-146.

33. Belagur, V.K.; Reddy, V. Performance, emission and combustion characteristics of direct injection diesel engine running on calophyllum inophyllum linn oil (honne oil). Int. J. Agric. Biol. Eng. 2011, 4, 26-34.

34. Banapurmath, N.; Tewari, P.; Hosmath, R. Performance and emission characteristics of a DI compression ignition engine operated on Honge, Jatropha and sesame oil methyl esters. Renew. Energy 2008, 33, 1982-1988. [CrossRef]

35. Akshatha, D.; Manavendra, G.; Kumarappa, S. Performance evaluation of Neem biodiesel on CI engine with diethyl ether as additive. Int. J. Innov. Res. Sci. Eng. Technol. 2013, 2, 3729-3736.

36. Habibullah, M.; Masjuki, H.H.; Kalam, M.; Fattah, I.R.; Ashraful, A.; Mobarak, H. Biodiesel production and performance evaluation of coconut, palm and their combined blend with diesel in a single-cylinder diesel engine. Energy Convers. Manag. 2014, 87, 250-257. [CrossRef]

37. Belagur, V.K.; Venkataramana, R. Injection timing impact on calophyllum inophyllum linn oil (Honne Oil)/diesel fuelled diesel engine. Int. Energy J. 2011, 11, 145-152.

38. Monirul, I.; Masjuki, H.; Kalam, M.; Mosarof, M.; Zulkifli, N.; Teoh, Y.; How, H. Assessment of performance, emission and combustion characteristics of palm, Jatropha and Calophyllum inophyllum biodiesel blends. Fuel 2016, 181, 985-995. [CrossRef]

39. Mosarof, M.; Kalam, M.; Masjuki, H.; Alabdulkarem, A.; Ashraful, A.; Arslan, A.; Rashedul, H.; Monirul, I. Optimization of performance, emission, friction and wear characteristics of palm and Calophyllum inophyllum biodiesel blends. Energy Convers. Manag. 2016, 118, 119-134. [CrossRef]

40. Wategave, S.P.; Banapurmath, N.R.; Sawant, M.S.; Soudagar, M.E.M.; Mujtaba, M.A.; Afzal, A.; Basha, J.S.; Alazwari, M.A.; Safaei, M.R.; Elfasakhany, A.; et al. Clean combustion and emissions strategy using reactivity controlled compression ignition (RCCI) mode engine powered with CNG-Karanja biodiesel. J. Taiwan Inst. Chem. Eng. 2021, in press. [CrossRef]

41. Mujtaba, M.A.; Cho, H.M.; Masjuki, H.H.; Kalam, M.A.; Farooq, M.; Soudagar, M.E.M.; Gul, M.; Ahmed, W.; Afzal, A.; Bashir, S.; et al. Effect of alcoholic and nano-particles additives on tribological properties of diesel-palm-sesame-biodiesel blends. Energy Rep. 2021, 7, 1162-1171. [CrossRef] 